\title{
ANÁLISE MOLECULAR (via RAPD) DE PLANTAS DE CANA-DE- AÇÚCAR DERIVADAS DA CULTURA DE MERISTEMA
}

\author{
Maria Imaculada Zucchi \\ Bióloga
}

Orientadora: Profa. Dra. MARIA LÚCIA CARNEIRO VIEIRA

Dissertação apresentada à Escola Superior de Agricultura "Luiz de Queiroz", Universidade de São Paulo, para obtenção do Título de Mestre em Agronomia, Área de Concentração: Genética e Melhoramento de Plantas

\author{
PIRACICABA \\ Estado de São Paulo - Brasil \\ novembro/1998
}


Dados Internacionais de Catalogação na Publicação (CIP) DIVISÃO DE BIBLIOTECA E DOCUMENTAÇÃO - Campus "Luiz de Queiroz"/USP

Zucchi, Maria Imaculada

Análise molecular (via RAPD) de plantas de cana-de-açúcar derivadas da cultura de meristema / Maria Imaculada Zucchi. - Piracicaba, 1998.

67 p. : il.

Dissertação (mestrado) - - Escola Superior de Agricultura Luiz de Queiroz, 1998. Bibliografia.

1. Cana-de-açúcar 2. Cultura de tecido vegetal 3. Marcador molecular 4. Propagaçāo "in vitro" 5. Variação Somaclonal I. Titulo 
Dedicada a Deus 


\section{AGRADECIMENTOS}

À Profa. Maria Lúcia Carneiro Vieira, pela orientação, amizade e confiança.

À Universidade Federal de São Carlos, campus de Araras, em especial ao pesquisador Hideto Arizono, pelo apoio no trabalho e pela amizade.

Ao laboratório da Secção de Biologia Molecular e Fitopatologia do Centro de Tecnologia da Copersucar, nas pessoas de Dr. Eugênio César Ulian, Dr. Carlos Gonzaga, Dr. Jorge A. da Silva, Ms. Vicente Alberto Morais e às colegas Andréia, Daniela Braga, Daniela Volpato, Paula, Noemia e Rosângela.

Ao Departamento de Genética da ESALQ/USP e a todos os seus professores pelos conhecimentos transmitidos, em especial ao Professor Paulo Sodero Martins (in memoriam), pelo exemplo de vida e profissionalismo deixado para nós.

Ao CNPq e à CAPES, pela concessão das bolsas de estudo e à FAPESP pela concessão de verba ao projeto.

Aos colegas Francisco, Adriana, llene e Vera pela revisão do texto deste trabalho.

Aos colegas do Curso de pós graduação em Genética e Melhoramento de Plantas da ESALQ/USP e do Laboratório de Biologia Celular e Molecular de Plantas: Mariza, Julieta, Carlinhos, Lissandra, Ilene, Vera, Adriana, Paulo Augusto, Aldete, Gustavo, Cris, Mona, Heiko, Bete, Luciana, Luciana Barbosa pela excelente convivência no laborátorio, amizade, união e solidariedade. Agradeço especialmente Vera, Adriana e Maria Cristina.

Ao Carlos Alberto de Oliveira, técnico do laboratório de Biologia Celular e Molecular de Plantas e a seus pais, D. Marilene e Sr. Lázaro pela amizade e carinho durante este período.

Aos meus pais: Ivani e Mathilde, minhas irmãs: Silvana, Denize, Maria do Rosário e Maristela e à toda família, pelo constante apoio, carinho e amizade, sem os quais esta dissertação não teria sido realizada.

Ao Baldin, por todo apoio e comprensão que teve durante a realização deste trabalho. 


\section{SUMÁRIO}

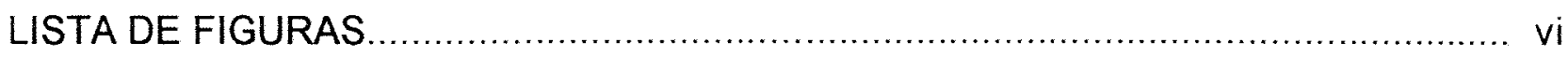

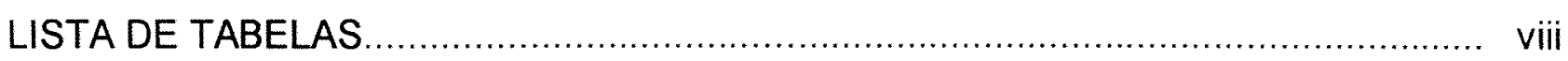

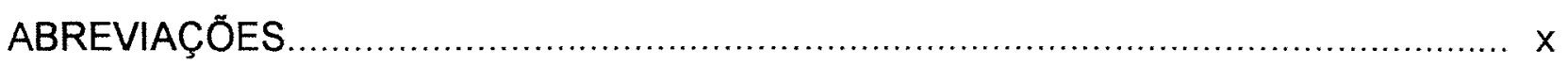

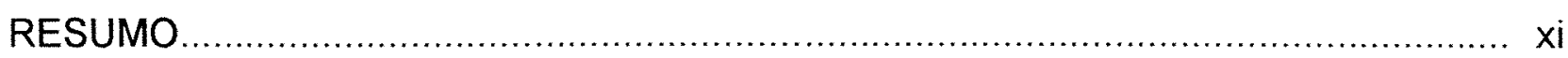

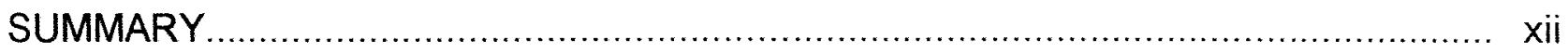

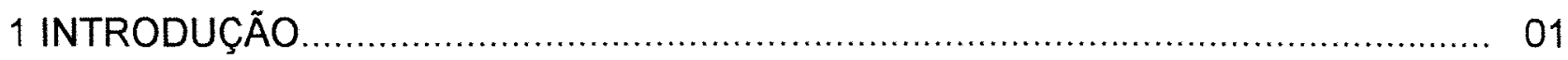

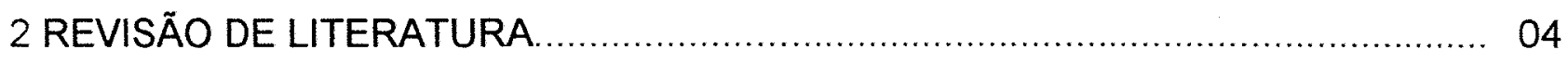

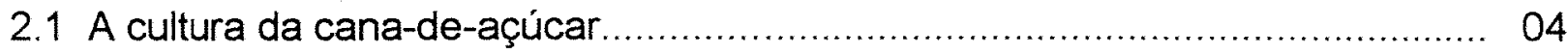

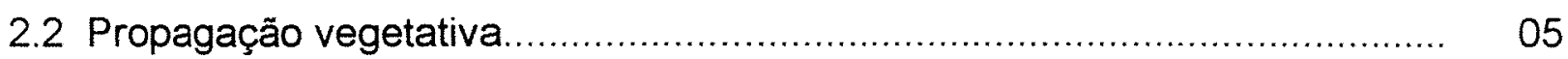

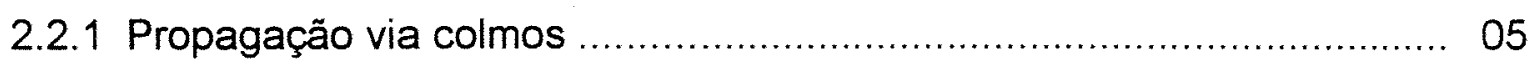

2.2.2 Cultura de meristema.............................................................. 05

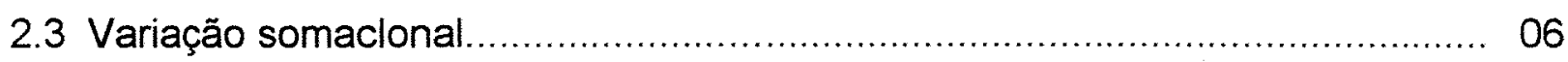

2.3.1 Natureza genética da variação somaclonal......................................... 08

2.3.2 Alterações cromossômicas......................................................... 10

2.3.3 Hipo e hipermetilação do DNA nuclear .......................................... 12

2.3.4 Ativação de elementos transponiveis.............................................. 13

2.3.5 Modificações no DNA citoplasmático............................................ 15

2.4 Detecção da variação somaclonal por marcadores moleculares.................... 17

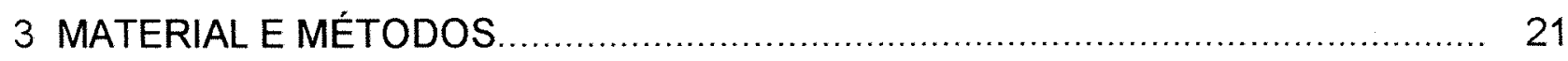

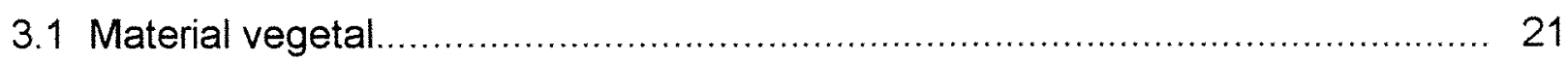

3.1.1 Coleta de plantas de campo, oriundas da cultura de meristema.......... 21

3.1.2 Coleta de plântulas cultivadas in vitro ............................................ 23

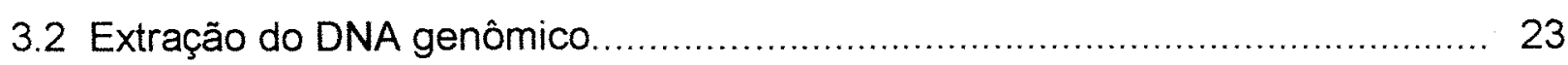

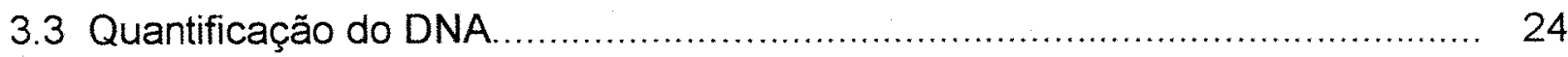

3.4 Condições de amplificação ................................................................... 25

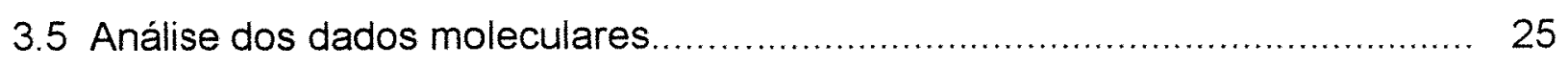

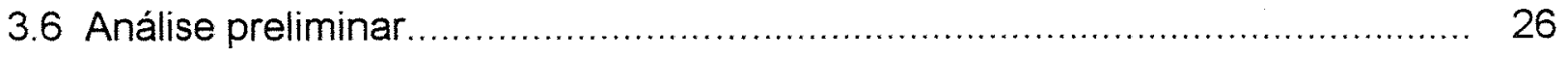

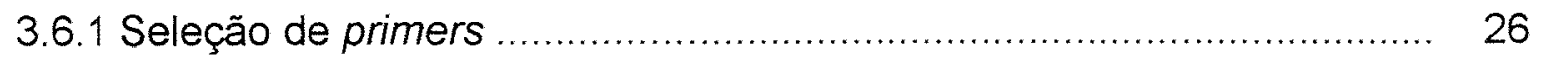




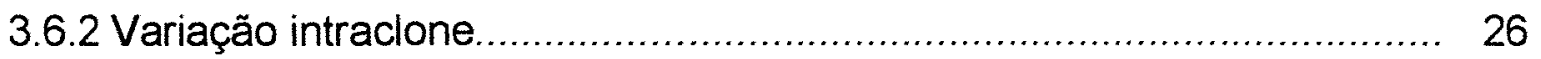

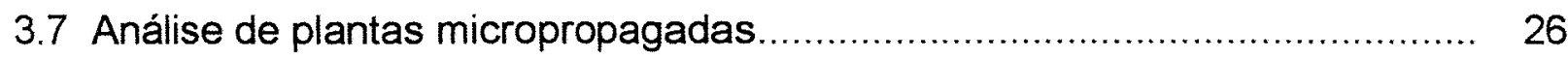

3.7.1 Coletadas no campo experimental.............................................. 26

3.7.2 Coletadas de culturas in vitro.......................................................... 30

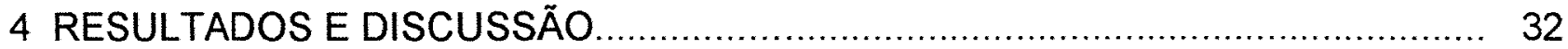

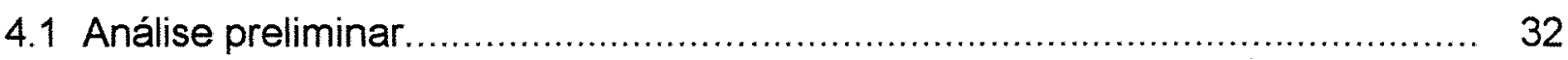

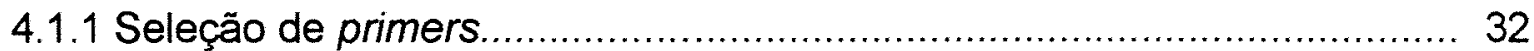

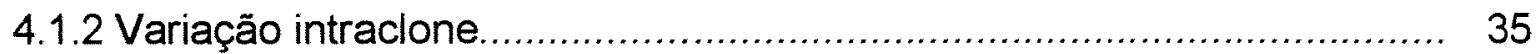

4.2 Análise de plantas de campo oriundas da cultura de meristema................... 41

4.3 Análise de plântulas cultivadas in vitro ............................................... 48

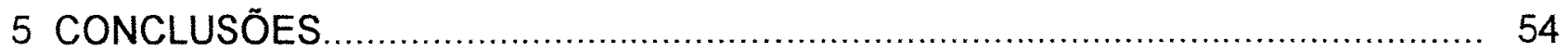

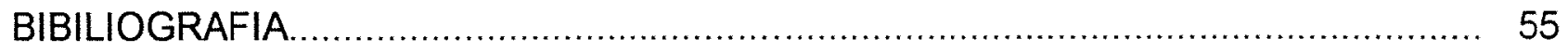




\section{LISTA DE FIGURAS}

Página

1 Plantas de cana-de-açúcar da variedade RB83-5486, propagadas via cultura de meristema, mostrando o caule da planta mãe ao lado dos somaclones designados $M 1$ (Mutante 1), M2, M3 e M4

2 Plantas de cana-de-açúcar da variedade RB83-5486, propagadas via cultura de meristema, mostrando à esquerda, plantas com caule anormal, ao lado de plantas normais.

3 Plantas da variedade RB83-5486, propagadas via cultura de meristema, mostrando as principais características afetadas, como calosidade, achatamento nos colmos (a) e gemas múltiplas (b).

4 Perfil de RAPD para 9 plantas de cana-de-açúcar: 2 da variedade RB835089 e 7 da variedade RB83-5486: 2 plantas testemunhas e 5 morfológicamente alteradas $\left(M_{1}, M_{2}, M_{3}, M_{4}\right.$ e $\left.M_{5}\right)$, analisadas com $\circ$ primer OPA-08, mostrando polimorfismo em $M_{2}, M_{3}$ e $M_{5}$. As amplificações foram feitas a partir de duas concentrações de DNA, 20 e $40 \mathrm{ng}$. À esquerda está o marcador de peso molecular (Ladder 100 bp).

5 Perfil de RAPD para 48 plantas de cana-de-açúcar da variedade RB835486 , que foram propagadas vegetativamente, analisadas com o primer OPA-02, mostrando monomorfismo entre os clones. À esquerda está o marcador de peso molecular (Ladder $100 \mathrm{bp}$ )...... 
6 Perfil de RAPD para 48 plantas de cana-de-açúcar da variedade RB835486, que foram propagadas pela cultura de meristema, analisadas com o primer OPA-18, mostrando polimorfismo entre os clones. À esquerda está o marcador de peso molecular (Ladder 100 bp).

7 Perfil de RAPD de 20 plantas de cana-de-açúcar da variedade RB835486 , provenientes de quatro meristemas $\left(\mathrm{Me}_{1}, \mathrm{Me}_{2}, \mathrm{Me}_{3}\right.$ e $\mathrm{Me}_{4}$ ) nas cinco fases de repicagens $(1,2,3,4$ e 5); primer OPA-02 (a) e OPA-04 (b), ambos perfis mostrando polimorfismo entre as repicagens. $\grave{A}$ esquerda está 0 marcador de peso molecular (Ladder 100 bp).

8 Número de locos polimórficos detectados em cada repicagem, considerando-se 50 plantas coletadas no campo, provenientes de dez meristemas

9 Perfil de RAPD de plantas de cana-de-açúcar da variedade RB83-5486, provenientes de um único meristema $(\mathrm{Me})$ nas seis fases de repicagens (1 a 6r); primer OPA-02 (a) e OPF-03 (b), ambos mostrando polimorfismo entre as repicagens. À esquerda está o marcador de peso molecular (Ladder $100 \mathrm{bp}$ ) e em seguida o perfil da planta mãe $(\mathrm{m})$, doadora do explante.

10 Número de locos polimórficos detectados em cada repicagem, considerando-se 30 plântulas da variedade RB83-5486 e 30 da variedade controle, SP80-185. 


\section{LISTA DE TABELAS}

Página

1 Suplementação de compostos orgânicos e de fitorreguladores para o cultivo de cana-de-açúcar em meio basal MS, conforme a fase do cultivo (em $\mathrm{mg} / \mathrm{L}$ )

2 Screening de primers polimórficos; usou-se quatro plantas testemunhas e quatro morfologicamente alteradas $\left(M_{1}, M_{2}, M_{3}\right.$ e $\left.M_{4}\right)$.

3 Polimorfismo induzido pela cultura de tecidos; usou-se quatro plantas testemunhas e cinco morfologicamente alteradas $\left(M_{1}, M_{2}, M_{3}, M_{4}\right.$ e $\mathrm{M}_{5}$ )

4 Polimorfismo intraclone em cana-de-açúcar; foram utilizadas 48 plantas normais, propagadas via colmos.

5. Polimorfismo induzido pela cultura de meristema; foram utilizadas 48 plantas anormais, micropropagadas

6 Polimorfismo molecular em plantas de cana-de-açúcar coletadas no campo, derivadas da cultura de meristema. Foram analisadas 20 plantas provenientes de quatro meristemas $\left(\mathrm{Me}_{1}, \mathrm{Me}_{2}, \mathrm{Me}_{3}\right.$ e $\left.\mathrm{Me}_{4}\right)$, em cinco fases de repicagem.

7 Polimorfismo molecular em plantas de cana-de-açúcar coletadas no campo, derivadas da cultura de meristema. Foram analisadas 20 plantas provenientes de quatro meristemas. $\left(\mathrm{Me}_{5}, \mathrm{Me}_{6}, \mathrm{Me}_{7}\right.$ e $\mathrm{Me}_{8}$ ), nas 5 fases de repicagem. 
8 Polimorfismo molecular em plantas de cana-de-açúcar coletadas no campo, derivadas da cultura de meristema. Foram analisadas 10 plantas provenientes de dois meristemas $\left(\mathrm{Me}_{9}\right.$ e $\mathrm{Me}_{10}$ ), em cinco fases de repicagem

9 Polimorfismo molecular em plântulas cultivadas in vitro. Foram analisadas 30 plântulas oriundas de cinco meristemas retirados da variedade SP80-185

10 Polimorfismo molecular em plântulas cultivadas in vitro. Foram avaliadas 30 plântulas oriundas de cinco meristemas retirados da variedade RB83-5486. 


\section{LISTA DE ABREVIATURAS}

$\begin{array}{ll}\text { CTAB } & \text { Brometo de hexadeciltrimetil-amônio } \\ \text { dNTPs } & \text { Desoxiribonucleosídeos trifosfatados (dATP, dTTP, dCTP e dGTP) } \\ \text { EDTA } & \text { Tetracetato de etileno diamino } \\ \text { TE } & \text { Tampão Tris/EDTA } \\ \text { TEB } & \text { Tampão Tris-borato/EDTA } \\ \text { TRIST } & \text { Hidroximetil aminometano } \\ \text { RFLP } & \text { Polimorfismo no comprimento de fragmentos de restrição } \\ \text { RAPD } & \text { Polimorfismo de DNA amplificado ao acaso } \\ \text { PCR } & \text { Reação da polimerase em cadeia } \\ \text { ICMS } & \text { Imposto sobre circulação de mercadorias } \\ \mathrm{bp} & \text { Pares de bases } \\ \mathrm{kb} & \text { Quilobases (1000 pb) } \\ \mathrm{PIB} & \text { Produto Interno Bruto } \\ \mathrm{min} & \text { Minutos } \\ \mathrm{rpm} & \text { Rotações por minuto } \\ \mathrm{mL} & \text { Mililitros } \\ \mu \mathrm{LL} & \text { Microlitros } \\ { }^{\circ} \mathrm{C} & \text { Centígrados } \\ \mathrm{pH} & \text { Potencial hidrogênio-iônico } \\ \mathrm{mM} / \mathrm{M} & \text { Milimolar/molar } \\ \mathrm{p} / \mathrm{v} & \text { Peso por volume } \\ \end{array}$




\title{
ANÁLISE MOLECULAR (via RAPD ) DE PLANTAS DE CANA-DE- AÇÚCAR DERIVADAS DA CULTURA DE MERISTEMA
}

\author{
Autora: Maria Imaculada Zucchi \\ Orientadora:Prof. Dra. Maria Lúcia Carneiro Vieira
}

\section{Resumo}

Cerca de um terço das mudas de cana-de-açúcar, plantadas no Estado de São Paulo, tem sido produzida por micropropagação. Quando se pratica micropropagação pretende-se conservar a integridade genética da planta doadora de explante, visto que a finalidade desta técnica é a obtenção de muitos clones com características idênticas às da planta doadora.

Porém, tem-se observado elevados niveis de instabilidade fenotípica em plantas micropropagadas, como na variedade RB83-5486. Neste, trabalho utilizou-se a técnica do RAPD com a finalidade de detectar a variação induzida pela cultura de tecidos em cana-de-açúcar.

Foram analisadas 48 plantas propagadas via colmos e 48 plantas micropropagadas (via cultura de meristema) da variedade RB83-5486. Calculou-se a taxa de polimorfismo a partir de 98 locos, sendo constatado um aumento do polimorfismo de $1,02 \%$ para $7,14 \%$, com incremento de cerca de sete vezes na taxa de polimorfismo.

Posteriormente, foram analisadas 50 plantas no campo, provenientes de dez meristemas nas cinco fases de repicagens, e 30 plantas in vitro provenientes de 5 meristemas nas seis fases de repicagens, em duas variedades. Encontrou-se taxas de polimorfismo variáveis em todas as fases do cultivo in vitro. $E$ a variedade RB83-5486 mostrou ter um comportamento in vitro mais instável quando comparada com a variedade SP80-185. 


\title{
MOLECULAR ANALISYS (via RAPD) OF SUGAR CANE PLANTS DERIVED FROM MERISTEM CULTURE
}

\author{
Author: Maria Imaculada Zucchi \\ Adviser : Profa. Dra. Maria Lúcia Carneiro Vieira
}

\section{Summary}

Approximately a third part of sugar cane plants in São Paulo State has been produced by micropropagation. As far as micropropagation is concerned, it is desirable to preserve genetic integrity of the explant donor plant, since the aim of this technique is to obtain many clones with characteristics identical to the donor plant.

However, high levels of phenotypic instability has been observed in micropropagated plants, such as variety RB83-5486. In the present work, RADP technique was employed in order to detect tissue culture-induced variations in sugar cane.

Forty-eight plants propagated via stem and forty-eight micropropagated plants (via meristem culture) from variety RB83-5486 were analised. The polymorphism rate was calculated from ninety-eight loci and an increase from $1,02 \%$ to $7,14 \%$ was observed, representing approximately a sevenfold higher polymorphism rate.

Fifty field-grown plants, from ten meristems at each one of the five subcultivation stages, and thirty in vitro plants from five meristems at each one of the six subcultivation stages, from two varieties were analysed. Different polymorphism rates were found at every in vitro cultivation phase. Concerning to the multiplication phase, we found variable polymorphism rates. Variety RB835486 appeared to have a more unstable in vitro behavior than variety SP80-185. 


\section{INTRODUÇÃo}

O Brasil foi um dos primeiros paises a produzir, em larga escala, o açúcar de cana. A cana-de-açúcar (Saccharum sp.) é a principal fonte de matéria-prima para a produção de açúcar, seguida pela beterraba açucareira (Beta vulgaris). Muitos países são produtores, porém apenas 11 são responsáveis por cerca de $80 \%$ da produção total de cana-de-açúcar, sendo o Brasil o primeiro produtor mundial (Mitsui, 1995).

Dados da FAO (Food and Agriculture Organization of the United Nations) revelaram que em 1990 a área colhida de cana no mundo era de 16.878 milhões de hectares, sendo o Brasil responsável por aproximadamente um quarto desta área.

A cultura da cana-de-açúcar, no Brasil, possui importância histórica, econômica, social e política. A indústria sucroalcoleira viveu um de seus maiores momentos quando o álcool passou a ser utilizado como combustível de automotivos, incentivado pelo Programa Nacional do Álcool, o Proálcool, criado em 1975/76. Nesta época, a produção de álcool era de 600 mil $\mathrm{m}^{3}$ /ano. Em 1985, no auge do Programa, $96 \%$ da frota automobilística produzida no pais possuía motores movidos a álcool. Na safra de 1991/92, a produção de álcool anidro atingiu 12,3 milhões $\mathrm{m}^{3} / a n o$ e continuou neste patamar até a safra de 1995/96. Mas, a despeito de todo o sucesso, o programa foi abandonado e hoje está à deriva (Falco, 1998).

A implantação do Proálcool, na década de 70 , exigiu um aumento da produção do álcool sem prejuízo para o açúcar consumido. Houve um 
crescimento na área cultivada no país, principalmente na região sudeste, sendo o Estado de São Paulo o maior produtor (Fernandes, 1996).

O setor sucroalcooleiro responde por cerca de $2 \%$ do PIB do Estado de São Paulo. As 150 usinas e destilarias de São Paulo estão distribuídas por vários municípios e, em muitos casos, contribuem para geração de mais de $50 \%$ do ICMS local. Dos cerca de 800 mil empregos gerados na agricultura paulista, cerca de 300 mil são fornecidos pela cana-de-açúcar (Baccarin, 1996).

Atualmente, parte das mudas de cana-de-açúcar são produzidas pela técnica de cultura de tecidos. A cultura é feita retirando-se o meristema de brotos recém-germinados (em torno de 30 dias), seguindo-se uma série de subcultivos em meio líquido, por 6 a 7 meses (Lee, 1987). Com índice de multiplicação em torno de 8 plântulas/frasco e com 1 subcultivos/mês, é possível se chegar, a partir de um meristema, a 20 mil plantas (Morais ${ }^{1}$ ).

O emprego da técnica de micropropagação de cana-de-açúcar, a partir de meristemas apicais, tem utilidade em programas de melhoramento devido à economia de tempo na multiplicação de variedades e clones promissores, facilitando a aquisição de grandes volumes do material desejado. Além da produção de mudas em larga escala, a cultura de meristema pode ser vista como um recurso a ser utilizado tanto para a propagação clonal de variedades, como para a limpeza de patógenos, pois as plantas oriundas de cultura de meristema são sadias, livres de microrganismos.

No Estado de São Paulo existem cerca de 15 biofábricas de canade-açúcar dando suporte às maiores usinas. Cerca de um terço da cana plantada atualmente provém da cultura de meristema.

A cultura de tecidos tem importância para a micropropagação $e$ indexação clonal de várias espécies de valor econômico. O que se explora é a totipotência celular, ou seja, a capacidade de uma única célula se dividir sucessivamente e gerar um organismo completo mantendo as mesmas características genéticas da célula-mãe (Mantell et al.,1994). Indivíduos portadores de alterações genéticas decorrentes dos estresses a que estão 'Morais, V. A. (Centro de Tecnologia Copersucar - Piracicaba) Comunicação pessoal, 1996. 
sujeitas as células in vitro são denominados de variantes somaclonais (Larkin \& Scowcroft, 1981)

Tem-se observado, elevados níveis de instabilidade fenotípica em espécies micropropagadas inclusive, em plantas de cana-de-açúcar (Burner \& Grisham, 1995; Bailey \& Bechet, 1989; Irvine, 1984 e Irvine et al., 1991). A variedade RB83-5486, quando micropropagada através da cultura de meristema, apresenta uma taxa elevada de variação somaclonal, comprometendo sua produção comercial.

A literatura relata alterações ao nível de DNA em plantas oriundas da cultura in vitro (Phillips et al.,1990; Chowdhury et al., 1988; Brears et al., 1989; Brettell et al., 1991 e Kuntake et al., 1998), inclusive em plantas derivadas da cultura de meristema (Damasco et al. 1996), utilizando técnicas que revelam marcadores moleculares. Entre estas metodologias usadas para a caracterização e detecção da variação somaclonal inclui-se a técnica do RAPD, que é capaz de detectar variações oriundas da cultura de tecidos em cana-deaçúcar e em outras espécies (Vallés et al., 1993 e Taylor et al., 1995). Este trabalho teve por finalidade estudar o fenômeno da variação somaclonal, via RAPD, em plantas de cana-de-açúcar com instabilidade fenotípica. Em paralelo, clones normais, do ponto de vista morfológico, foram analisados. 


\section{REVISÃO DE LITERATURA}

\subsection{A cultura da cana-de-açúcar}

A cana-de-açúcar é uma gramínea perene. Pertence ao gênero Saccharum, tribo Andropogoneae, juntamente com o gênero Zea e Sorghum Seis espécies de Saccharum são reconhecidas: $S$. officinarum, $S$. sinense, $S$. barberi, S. edule, S. spontaneum e S. robustum (Daniels \& Roach, 1987).

A origem e a evolução de $S$. officinarum são aspectos bastante complexos de sua história evolutiva e domesticação. Há controvérsias entre os autores, uma vez que estão, provavelmente, envolvidas em tal processo, a hibridação entre as espécies selvagens $S$. spontaneum e $S$. robustum, assim como hibridações naturais com gêneros pertencentes ou não ao complexo Saccharum e ainda espécies desconhecidas ou já extintas.

As variedades modernas de cana-de-açúcar são híbridos complexos sintetizados a partir de S. officinarum (cana nobre), S. barbieri (cana da Índia), S. sinense (cana chinesa) e duas espécies selvagens, S. spontaneum e $S$. robustum. A participação de $S$. robustum é restrita a poucas variedades do Havaí. Os genes para acúmulo de sacarose provêm de $S$. officinarum, S.barberi e $S$. sinense. O genoma da espécie selvagem $S$. spontaneum tem contribuído para a introgressão de genes de resistência a doenças, tolerância a estresses ambientais e produção de biomassa (Sreenivasan et al., 1987).

O centro de diversidade de Saccharum officinarum é, sem dúvida, a Nova Guiné, mas o centro de origem não está ainda definido (Daniels \& 
Roach, 1987). Supõe-se que a cultura tenha se originado na região leste da Indonésia e Nova Guiné.

\subsection{Propagação vegetativa}

\subsubsection{Propagação via colmos}

Tradicionalmente, no Brasil, a cana-de-açúcar tem sido propagada vegetativamente, através do plantio de colmos. O plantio é feito geralmente com cerca de 6 gemas sadias por metro de sulco nos espaçamentos convencionais de plantio $(1,30$ a $1,50 \mathrm{~m})$. São feitos vários viveiros multiplicadores de mudas para se conseguir um grande número de gemas a serem utilizadas posteriormente para o plantio comercial.

\subsubsection{Cultura de meristema}

Recentemente cerca de um terço das mudas plantadas no Estado de São Paulo tem sido fornecidas através da cultura de meristema. A cultura é feita retirando-se o meristema de brotos recém-germinados (em torno de 30 dias), seguindo-se uma série de subcultivos em meio líquido, por 6 a 7 meses. Com índice de multiplicação em torno de 8 plântulas/frasco e com 1 subcultivo/mês, é possível se chegar a partir de um meristema a 20 mil plantas (Morais'1).

O emprego da técnica de micropropagação de cana, a partir de meristemas apicais, tem utilidade devido à economia de tempo na multiplicação de variedades e também de clones promissores, facilitando a aquisição de grandes volumes do material desejado. Além da produção em larga escala, a cultura de meristema pode ser vista como um recurso para a limpeza de ${ }^{1}$ Morais, V. A. (Centro de Tecnologia Copersucar - Piracicaba) Comunicação pessoal, 1996. 
patógenos, pois as plantas oriundas deste processo de meristema são sadias, livres de microrganismos.

Certos cuidados são necessários para o início da cultura de meristema em cana-de-açúcar. É necessário que os colmos utilizados para germinação de brotos, os quais serão futuramente usados como fonte de explantes, passem por tratamento térmico $\left(50^{\circ} \mathrm{C}\right.$ por $\left.30 \mathrm{~min}\right)$ para desinfestação de microrganismos. Posteriormente, estes colmos são plantados em substrato (torta de filtro e terra), em casa de vegetação.

Atualmente, no Estado de São Paulo, é feita a retirada do meristema na biofábrica do CTC (Centro de Tecnologia Copersucar, localizada em Piracicaba) e as diversas fases da cultura in vitro ocorrem em meio líquido, com diferentes fitorreguladores e vitaminas. Na primeira fase do cultivo, o meristema atinge cerca de $2 \mathrm{~cm}$ de comprimento; este meristema é então transferido para a segunda fase (mutiplicação) quando são levados para as usinas cooperadas onde serão feitas as repicagens. Na segunda fase, são utilizadas auxinas e citocininas responsáveis pelo perfilhamento. Na terceira fase, as plântulas são cultivadas em meio de cultura no qual ocorre o enraizamento. Estas plântulas são então transplantadas para casa de vegetação em substrato de torta de filtro e terra, onde são submetidas a aspersões ou nebulizações para a manutenção da alta umidade do ar $e$, finalmente, são transplantadas para o campo.

Os principais problemas oriundos do processo da cultura de meristema são: (i) a ocorrência de contaminações e oxidações, (ii) a incidência de mutações genéticas, (iii) os desarranjos fisiológicos e, (iv) o excesso de repicagens.

\subsection{Variação Somacional}

A variação somaclonal pode ser definida como qualquer variação de natureza genética, citogenética ou molecular originada durante as fases 
iniciais da cultura de tecidos (indução de calos, por exemplo) ou na fase de regeneração de plantas (Larkin \& Scowcroft, 1981). Portanto, está sempre associada a processos de regeneração de plantas a partir do cultivo in vitro.

Segundo Larkin \& Scowcroft (1981), a variação somaclonal é frequente e está presente em diferentes espécies e gêneros. Tem sido descrita em diferentes níveis de ploidia, em plantas de fecundação cruzada e autofecundação, em plantas de propagação vegetativa e por sementes, em plantas cultivadas ou não. São mudanças genéticas, podendo envolver características qualitativas ou quantitativas, simples mutações ou até mudanças drásticas no nível de ploidia, aneuploidias, aberraçōes cromossômicas estruturais e, igualmente, mutações citoplasmáticas (Larkin \& Scowcroft, 1983 e Scowcroft et al., 1985).

A primeira citação sobre variantes somaclonais em plantas regeneradas foi descrita por Butenko et al. (1967), analisando regenerantes de culturas de calos de fumo. Foi criado, 14 anos mais tarde, o termo variação somaclonal por Larkin \& Scowcroft (1981), para designar o surgimento de variantes genéticos a partir da cultura de células in vitro.

Alguns fatores como tempo de cultura, número de subcultivos, fitorreguladores, tipo de explante, genótipo, composição do meio de cultura, nível de ploidia e mosaicismo são considerados agentes capazes de induzir variabilidade in vitro (Silvarolla, 1992). Os mecanismos que causam eventos mutacionais na natureza são os mesmos que ocorrem no sistema in vitro, apenas estes eventos ocorrem em maior frequência.

O estresse in vitro, pode ser ocasionado pelo descontrole do ciclo celular. Os meios de cultura geralmente possuem hormônios que aceleram o ciclo celular $e$ isto pode comprometer a integridade do material genético propagado. A rápida mutiplicação celular pode ser responsável por quebras cromossômicas. Regiões de replicação tardia, como as regiões heterocromáticas, têm sido indicadas como sítios onde há quebras cromossômicas e consequentemente formação de pontes anafásicas (Santos, 1995). 
As modificações genéticas que explicam a variação somaclonal podem ser ocasionadas por: aberrações cromossômicas, mutações de ponto, ativação de elementos transponiveis, amplificação gênica, alterações no DNA das organelas, mudanças na quantidade de DNA total e no número de cópias do DNA repetitivo (Phillips et al., 1990). As causas não-genéticas, podem ser de natureza fisiológica ou epigenética (metilação do DNA, por exemplo).

Fenotipicamente, plantas regeneradas que apresentam variação somaclonal são distinguidas por aspectos morfológicos anormais, tais como: nanismo, alterações em caracteres foliares, quimerismos, mosaicismo das folhas, albinismo, alterações de fertilidade e variações morfogenéticas (Heinz \& Mee,1971 e Damasco et al., 1996). No caso particular da cana-de-açúcar, o estreitamento do diâmetro do colmo e da folha, calosidade nos internós e superbrotação das gemas laterais são as principais características que aparecem em plantas submetidas ao estresse in vitro (Burner \& Grisham, 1995; Irvine, 1984 e Irvine et al., 1991).

\subsubsection{Natureza genética da variação somaclonal}

Uma das maiores dificuldades relacionadas à variação somaclonal é determinar a sua base. Diversos mecanismos ou tipos de alterações têm sido propostos para explicar tal evento segundo Evans (1989), Larkin \& Scrowcroft (1981), Silvarolla (1992) e Pesche \& Phillips (1992):

a) alterações genéticas, como mutações de ponto, alterações no DNA citoplasmático e nos elementos transponiveis, amplificação e deleção gênicas.

b) alterações gênicas, afetando caracteres quantitativos e/ou qualitativos.

c) alterações citogenéticas, envolvendo aberrações estruturais ou numéricas.

d) alterações epigenéticas: ocorrem em sistemas onde não há transmissão sexual da variação, ou seja, são variaçōes não herdáveis.

Mudanças genéticas de vários tipos têm sido demonstradas em 
experimentos de cultura de tecidos. Aberrações cromossômicas e mudanças no nível de ploidia têm sido indicadas como sendo a causa maior da variação somacional (D'Amato, 1991).

O material submetido à cultura in vitro pode não ser geneticamente homogêneo $e$ isto pode ser avaliado pela proliferação de diferentes tipos celulares. Este evento é conhecido como mosaicismo e vários autores têm observado a sua ocorrência em plantas de cana-de-açúcar (Heinz \& Mee,1971).

As culturas in vitro podem ser iniciadas a partir de tecidos complexos, constituídos de células nas diversas fases do ciclo celular, exibindo diferentes etapas de desenvolvimento e níveis de ploidia e, em casos de mosaicismo, com diferentes números de núcleos (Meins Jr., 1983). Por isso, a fonte e idade de explante irão influenciar na variação somaclonal observada em cultura (Peschke \& Phillips, 1992). A ploidia da fonte de explante influencia na frequência da variação ocorrida. Poliplóides demostram possuir maior taxa de variação somaclonal que diplóides (Fish \& Karp, 1986). Em plantas de batata regeneradas a partir de protoplastos, os poliplóides apresentaram uma maior instabilidade genética. Em média, 50\% mantiveram seu nível de tetraploidia igual a 48 cromossomos e 10 a 15\% eram aneuplóides oriundos de tetraplóides ou octoplóides (Fish \& Karp, 1986).

A cultura de meristemas é considerada como um procedimento que produzirá pouca ou nenhuma variação somaclonal, pois as células submetidas ao cultivo in vitro não passam por um estádio de desdiferenciação; quando comparado com outros processos in vitro, nos quais um estado de desdiferenciação é induzido, como na cultura de calos, onde a incidência de variação somaclonal tende a ser maior (Potter \& Jones, 1991, citados por Pesche \& Phillips, 1992). A cultura de calos também apresenta maior variação quando comparada à embriogênese somática e organogênese diretas e cultura de protoplastos (Fish \& Karp, 1986).

Existem vários relatos na literatura demonstrando que a cultura in vitro induz variabilidade. Segundo Phillips et al. (1990) a cultura de tecidos é um 
procedimento mutagênico, provocando estresse no genoma, que é levado a responder, de modo incomum, dando origem aos somaclones. Os fitoreguladores são os principais componentes de meio de cultura que têm ação mutagênica, com ênfase no 2,4-D (ácido 2,4 diclorofenoxiácetico). Também, a pureza e concentração dos sais utilizados na formulação dos meios basais são questionadas quanto ao seu papel estressante para o genoma de plantas cultivadas in vitro.

Porém, não só variáveis intrínsecas ao meio de cultura induzem variação somaclonal pois existe interação genótipo $x$ meio de cultura. Certos genótipos, como a variedade de cana-de-açúcar RB83-5486, talvez não se prestem para a cultivo in vitro da forma como é feito atualmente para os demais genótipos.

\subsubsection{Alterações cromossômicas}

As alterações cromossômicas provocadas pela cultura de tecidos são, principalmente, poliploidias além das aneuploidias, translocações, inversões, deleções, duplicações e substituições cromossômicas.

A indução in vitro da poliploidia consiste num fenômeno semelhante à endorreduplicação, no qual ocorre a duplicação do número cromossômico. A aneuploidia, deleção ou duplicação de segmentos cromossômicos inteiros, constituem-se nos principais eventos que condicionam a variação observada em materiais submetidos ao cultivo in vitro. Geralmente, a aneuploidia ocorre por quatro mecanismos: não-disjunção cromossômica, retardo cromossômico, fusos aberrantes ou quebras cromossômicas.

Aberrações estruturais são aquelas que modificam a estrutura dos cromossomos, e são igualmente responsáveis por parte da variação somaclonal observada nas culturas in vitro. Estas modificações estruturais envolvem quebras casuais sítio-específicas ao longo dos cromossomos. Há relatos de que os quatro tipos de aberrações estruturais, isto é, as translocações, 
inversões, deleções e duplicações, ocorrem in vitro.

Muitos estudos têm mostrado que mudanças na estrutura de cromossomos podem ocorrer durante o cultivo in vitro. Análises citológicas de plantas regeneradas têm mostrado incidência de quebras cromossômicas e suas consequências. $E$ estas têm sido frequentemente associadas a regiões de heterocromatina de replicação tardia (Phillips et al.,1990).

Santos et al. (1995) e Fluminhan et al. (1996), verificaram a ocorrência de instabilidade mitótica em cultura de calos embriogênicos de milho. Pontes e fragmentos cromossômicos foram detectados na anáfase e telófase. Com a técnica de bandamento- $C$, foi possivel detectar a presença de knobs nos braços cromossômicos envolvidos na quebra. A análise de bandamento- $C$ na anáfase e metáfase forneceu evidências da ocorrência de ciclos de quebra-fusão-ponte in vitro, envolvendo o cromossomo 7 resultando em um cromossomo com um knob a mais no braço curto.

Peschke \& Phillips (1992) concluíram que a posição das quebras cromossômicas não é casual, mas envolvem regiões de replicação tardia, ou seja, regiōes de heterocromatina, geneticamente inativas, de papel estrutural e dispersa ao longo dos cromossomos de forma especifica ou não. Em função das regiões heterocromáticas replicarem mais tarde que o usual in vivo, no ambiente in vitro, as cromátides em separação tendem a manter-se juntas, estando sujeitas à quebra que ocorre, preferencialmente, entre o centrômero e a região heterocromática.

O ciclo quebra-fusão-ponte, proposto por McClintok (1984), explica os rearranjos cromossômicos que ocorrem após as quebras. Um cromossomo quebrado, após a replicação, teria seus finais aderentes, os quais tendem a se fundir. Durante a segregação das cromátides ocorre a formação de uma ponte, seguida de nova quebra em qualquer região, originando novamente um cromossomo quebrado que reiniciará o ciclo ou sofrerá cicatrização, permanecendo estruturalmente alterado. Este ciclo pode ocorrer várias vezes ou como evento único no início da cultura. Acredita-se que a ocorrência de quebras em um cromossomo pode levar à indução de quebras adicionais em 
outros cromossomos não envolvidos no ciclo original (Lee \& Phillips, 1987).

Joachimiak et al. (1993) estudando cariótipos de células de calos em culturas de longa duração em Allium verificaram anormalidades como: formação de micronúcleos e megacromossomos ou cromossomos gigantes. Verificou-se que estas anormalidades aumentaram conforme o tempo do cultivo in vitro.

Kunitake et al. (1998) observaram variações na ploidia de Asparagus officinalis oriundo da cultura de calos e essas variações cromossômicas aumentavam conforme o número de subcultivos e tempo de cultura. Foram observadas plantas haplóides e tetraplóides geradas pela cultura in vitro. Cerca de $80 \%$ das plântulas possuiam caracteres afetados. Um caráter bastante modificado foi altura das plantas, houve um excesso de plantas anãs.

\subsubsection{Hipo e hipermetilação do DNA}

A metilação está relacionada com a regulação da expressão gênica nos eucariontes. $O$ padrão de expressão gênica é alterado pela adição de grupamentos metil em nucleotídeos, principalmente em citosinas seguidas de guaninas, presentes nas sequências do DNA e por isso, a metilação tem sido sugerida como um mecanismo de controle epigenético (Holliday, 1987). Esta modificação é um processo pós-replicativo, estável, herdável, no qual há a transferência do grupamento metil da S-adenosilmetionina para a posição $5 \mathrm{da}$ citosina, ou para a posição 6 da adenina.

A porcentagem de citosinas metiladas varia nos eucariontes. Em vegetais superiores cerca de $30 \%$ de todas as citosinas apresentam o grupamento metil em ambos os sítios CG e CNG. A metilação tem seu papel principal na inativação do DNA não transcrito, impedindo-o de interagir com proteínas regulatórias. Atualmente, sabe-se que a metilação está associada a inibição da transcrição pela associação de proteínas específicas (MeCP1 e MeCP2) que se ligam ao DNA metilado (Lewin, 1994). 
Em cultura de tecidos, há relatos de que ocorre um incremento das taxas de metilação (hipermetilação) ou sua atenuação (hipometilação). Como consequência, há alterações nos processos de regulação da atividade gênica, hiper ou hipoativação de elementos transponíveis e modificações na estrutura da cromatina (Bretell \& Dennis, 1991 e Loschiavo et al., 1989).

Smulders et al. (1995) observaram diferentes padrões de metilação no DNA repetitivo em plantas de tomate regeneradas da cultura de calos. Isto foi detectado com a utilização de duas enzimas de restrição $\mathrm{Hpall/Mspl} \mathrm{que} \mathrm{são} \mathrm{isoesquizomêros.} \mathrm{Essas} \mathrm{enzimas} \mathrm{reconhecem} \mathrm{o} \mathrm{mesmo}$ sítio CCGG e a primeira cliva somente tetrâmeros não metilados enquanto a segunda cliva toda sequência CCGG quando a citosina externa a este sítio estiver ou não metilada.

Harding et al. (1996) observaram mudanças na metilação do DNA durante a micropagação e indução de calos de Vitis vinifera, analisando sequências de rDNA que foram metiladas durante o cultivo in vitro. Usando os isoesquisômeros Mspl/Hpall, analisaram plantas em casa de vegetação contendo $7,7 \%$ de citosinas metiladas. Na fase inicial da cultura in vitro, esta taxa aumentou para $64,5 \%$ e na fase final (quarto subcultivo) esta taxa aumentou ainda mais, atingindo $72,5 \%$. Os autores sugerem que 0 acréscimo da metilação ocorre com o aumento do tempo de cultivo in vitro e pode ter influência no processo de desenvolvimento e manutenção da totipotência resultando na recalcitrância, que é um problema grave no cultivo in vitro da uva.

\subsubsection{Ativação de elementos transponíveis}

Os elementos de transposição são sequências genéticas móveis dispersas no genoma de diversos organismos (McClintock, 1984). Sua distruibuição é bastante ampla na escala evolutiva, tendo papel fundamental na geração de variabilidade (Kunze et al., 1997). Estes elementos foram caracterizados inicialmente devido ao aparecimento de mutações instáveis que 
estes causam quando se inserem e se excisam de um gene (McClintock, 1984 e Kunze et al., 1997).

Os elementos genéticos móveis se dividem em duas grandes classes: retrotransposons, que se movem via um RNA intermediário, e elementos transponíveis, que se movem via DNA, e estas classes se dividem em grupos ou familias (Kunze et al., 1997).

Ambas as classes possuem elementos autônomos e defectivos. Os elementos autônomos possuem a capacidade de codificar proteínas necessárias para a sua transposição, enquanto elementos defectivos possuem deleções nessas sequências, sendo portanto imóveis. Sua mobilização depende do fornecimento destas proteínas por outros elementos autônomos existentes no genoma (Kunze et al., 1997 e Chomet et al., 1987).

Os retrotransposons são os elementos genéticos móveis mais abundantes em plantas. Ao todo, constituem uma fração substancial do genoma das plantas, chegando a ser, muitas vezes, mais de 40\%, (Heslop-Harrison et al., 1997). Em Vicia faba foi demostrado que um único tipo de retrotransposon ocorre a cada $106 \mathrm{pb}$. Assumindo que esta cópia possue o tamanho de $2 \mathrm{~kb}$, somente estas sequências representam 16\% do genoma (Kunze et al., 1997).

A metilação está relacionada com a regulação da expressão dos elementos genéticos móveis. A atividade dos elementos transponiveis tem sido relacionada com a redução da metilação em sítios especificos dentro destes elementos (Chomet et al., 1987; Fedoroff \& Chandler, 1994; Fedoroff, 1989 e Scortecci et al.,1997), assim como a hipermetilação tem causado o silenciamento desses elementos (Fedoroff et al., 1995).

McClintock (1984) atribuiu ao estresse genômico os estímulos endógenos e exógenos que permitem a ativação de elementos transponiveis. Uma hipótese, é que o estresse genômico induz a um dano no DNA causando rápida atividade de reparo após desmetilação, possibilitando a reativação transcricional de elementos transponíveis silenciosos (Kunze et al., 1997).

A propagação de plantas por cultura de tecidos tem induzido uma variedade de mudanças epigenéticas. A alteração no padrão de metilação tem 
sido proposta para explicar essas mudanças e um possivel mecanismo envolvido na indução de variação somaclonal é a ativação de elementos transponíveis. A ativação dos elementos Ac/Ds e Spm foi estudada por Peschke et al. (1987) e Peschke et al. (1991). Retrotransposons foram recentemente clonados com o auxílio da PCR, usando como primers sequências conservadas da transcritase reversa e tem sido verificada sua ativação durante o cultivo in vitro. Foi verificado que os retrotranposons foram ativados na cultura de protoplastos de fumo e que o número de cópias do elemento Tto1 aumentou cerca de dez vezes (Hirochika, 1993). Estes retroelementos também têm sido observados na cultura de tecidos de arroz, na qual o número de cópias aumentou conforme o tempo de cultura, chegando a cerca de 30 vezes (Hirochika et al., 1996).

Devido à forma através da qual eles se transpõem, os elementos transponiveis causam mutações instáveis enquanto os retrotransposons induzem mutações estáveis na cultura de tecidos (Hirochika, 1995, Hirochika et al., 1996).

\subsubsection{Modificações no DNA citoplasmático}

Marcadores moleculares tanto isoenzimáticos como os de DNA têm sido utilizados para estudos sobre o estresse causado pela cultura in vitro. Eles têm explicado alterações que ocorrem no genoma nuclear e citoplasmático (cloroplastidial e mitocondrial). Existem muitas evidências de modificações do DNA nuclear e citoplasmático induzidas pela cultura in vitro detectadas por meio de marcadores moleculares (Cloutier \& Landry, 1994). Essas modificações podem ocorrer no genoma e não ser expressas em proteinas pois ocorrem em espaçadores intra e inter-gênicos, íntrons ou regiões não-codantes do DNA. Este tipo de variação pode ser detectada por marcadores de DNA do tipo RFLP elou RAPD (Chowdhury et al., 1988).

Os RFLPs têm sido usados com sucesso na detecção da variação 
somaclonal em cana-de-açúcar. Chowdhury \& Vasil (1993) analisaram a estabilidade genética de regenerantes de cultura de tecidos de plantas oriundas de calos, suspensões celulares e protoplastos. O DNA total de três híbridos de cana-de-açúcar foi extraido e digerido com EcoRI, HindIII, BamHI + EcoRI e Pstl e as sondas usadas para hibridação foram de genes mitocondriais de milho (coxl, coxll, aptA, apt6, apt9 e rrn18-rn5). Variação no padrão de restrição foi observada somente no DNA extraído de suspensões celulares digerido com EcoRI, como padrão foi usado DNA de uma planta testemunha da variedade CP72-1210.

O genoma do cloroplasto (cpDNA) e da mitocôndria (mtDNA) tem uma única característica que os distingue do genoma nuclear: são moléculas circulares que existem em várias cópias dentro dessas organelas. A maioria do genoma mitocondrial de plantas existe sob a forma de uma população heterogênea de moléculas circulares. Recombinações levam à formação de uma subpopulação de moléculas circulares (Palmer \& Shields, 1984). Análises moleculares indicam que a integridade do genoma mitocondrial pode ser facilmente rompida durante a cultura de tecidos. Rearranjos têm sido observados em suspensão celular de Vicia faba, em suspensão celular de arroz, cultura de calos de beterraba, na embriogênese somática de trigo e em hibridos somáticos de espécies de Brassica (Cloutier \& Landry, 1994).

O genoma cloroplastidial é simples e consiste em somente uma molécula de DNA circular com pouco DNA repetitivo. Menor número de variações foram observadas nas moléculas de cpDNA durante o cultivo de arroz em suspensão celular (Chowdhury et al., 1988). Isto pode ser consequência da letalidade às células, que não suportam qualquer modificação nesse genoma (Brears et al., 1989).

Rode et al. (1989) analisaram plantas de trigo regeneradas a partir de embriogênese somática, através de RFLP, usando como sonda um segmento de mtDNA, e encontraram diferenças em relação às plantas controle que não passaram pela cultura de tecidos. Também observaram que a cultura de longa duração produziu maior variabilidade no DNA mitocondrial do que a 
cultura por tempo reduzido.

Breiman \& Shimron-Abarbanell (1991) analisaram plantas regenerantes de calos de Hordeum marinum com duas enzimas de restrição, usando como sonda sequências codantes e não codantes de DNA genômico e mitocondrial. Foram analisadas 50 plantas regenerantes as quais mostraram polimorfismo quando hibridizadas com sondas de mtDNA. Estes autores observaram que a cultura de tecidos pode induzir modificações no DNA mitocondrial de plantas regeneradas de calos e suspensões celulares.

Muitos estudos indicam que o tempo da cultura in vitro é a maior causa da instabilidade em DNAs mitocondriais. Assim, em suspensões celulares de arroz, foram observadas modificações nas sequências, sugerindo que houve um intenso rearranjo no mtDNA (Saleh et al., 1990).

\subsection{Detecção da variação somaclonal por marcadores moleculares}

Os primeiros estudos com marcadores moleculares associados a variação somaclonal surgiram em 1983. Os autores foram capazes de identificar variantes somaclonais através de marcadores isoenzimáticos. Brettell et al. (1986) encontraram diferenças no padrão eletroforético da enzima álcool desidrogenase (Adh1) em plantas oriundas da cultura de embriões imaturos de milho.

Dahleen et al. (1991) observaram diferenças no padrão de locos enzimáticos quando analisaram regenerantes da geração $R_{5}$ de diferentes linhagens de aveia (Avena sativa L.). Encontraram diferenças no padrão da proteína de reserva avenina (prolamina) e associados a estas foram observadas variações em características agronômicas.

Binsfield et al. (1996) observaram diferentes padrões eletroforéticos das enzimas esterase e peroxidase das plantas controles em relação aos dos somaclones. Foram utilizados 136 somaclones de três variedades diferentes de batata. Um dos cultivares, Santo Amor, apresentou 
cerca de $85,7 \%$ de polimorfismo, e o outros cultivares, Baronesa e Macaca, apresentaram cerca de $33,3 \%$ e $19,1 \%$, respectivamente.

As útimas décadas têm sido testemunhas do sucesso da aplicação das técnicas de cultura de tecidos em inúmeras espécies. Durante esse mesmo período, estudos de genética molecular têm crescido exponencialmente. Assim, o uso de marcadores moleculares, como ferramentas precisas para a deteç̧ão da variação induzida in vitro, tem sido indicado quando as características fenotípicas ou cariotípicas são inviáveis de serem analisadas.

Plantas de beterrraba (Beta vulgaris $L$.) regeneradas da cultura de tecidos foram analisadas por RFLP e isoenzimas. Pela técnica do RFLP analisou-se 60 plantas usando três sondas de CDNA e, através de oito sistemas isoenzimáticos, analisaram-se 756 plantas. O número de variantes isoenzimáticos e de RFLP, foi calculado pela porcentagem aproximada de alelos variantes, e esta taxa foi de 0,05 a 0,1\% (Ford-Lloyd et al., 1992).

A técnica de minisatélietes foi usada para gerar fingerprints em plantas de trevo (Trifolium pratense L.) com a finalidade de detectar polimorfismos em plantas derivadas da cultura de tecidos. Este trabalho evidenciou a existência de variação somaclonal, que não foi detectada morfologicamente (Nelke et al.,1993).

Polimorfismos têm sido detectados através de RFLP em plantas regeneradas da cultura de calos e em suspensão celular de arroz, quando comparadas com plantas controles. A frequência de polimorfismo detectado em plantas derivadas da cultura de protoplastos foi de $29 \%$. Na cultura de calos esta frequência variou de 6,3 a $23 \%$, dependendo do tempo da cultura, pois as culturas de calos de longa duração tendem a aumentar a frequência de polimorfismos (Brown, 1989 e Brown et al., 1991).

Marcadores RAPD têm sido utilizados com sucesso para analisar a estabilidade genética de plantas oriundas da cultura in vitro (Cônsoli, 1995; Schneider \& Zyprian, 1996; Taylor et al.,1995; Todoroviska et al.,1997 e Vallés et al., 1993)

Segundo Taylor et al. (1995) os RAPDs são um método adequado 
para a detecção de mudanças que ocorrem na cana-de-açúcar devido ao longo período de permanência em cultura, tanto de calos como de protoplastos.

Cônsoli (1995) verificou que a técnica do RAPD foi capaz de detectar polimorfismo entre plantas de Stylosanthes guianensis regeneradas a partir da cultura de tecidos e oriundas de sementes das populações originais, separando as progênies em grupos distintos.

Ford-Lloyd et al. (1996) analisaram regenerantes de beterraba (Beta vulgaris L.) derivadas de gemas adventícias regeneradas de explantes foliares. Utilizou-se apenas um genótipo, pois este possuía maior taxa de proliferação in vitro do que os demais. $\mathrm{Na}$ geração $\mathrm{R}_{1}$ foram obtidos 120 regenerantes, e 30 oriundos da geração $R_{2}$ foram analisados. No primeiro ciclo, cinco primers foram utilizados e o número total de bandas obtido foi de 4.557 , sendo apenas duas delas polimórficas. No segundo ciclo, em um total de 1.050 bandas analisadas foi observada uma nova banda polimórfica. No escore geral foram estudados 5.607 locos e observada uma frequência de $0,05 \%$ de polimorfismo. Este trabalho mostra que, independentemente da sua natureza dominante, a frequência de detecção de polimorfismo induzido em beterraba usando RAPD é muito similar às frequências obtidas usando isoenzimas e RFLP que são marcadores codominantes.

Hashimi et al. (1997) utilizaram com sucesso técnica do RAPD para a detecção de diferenças genéticas entre variantes somaclonais derivados da cultura de embriões de dois cultivares de pêssego. Utilizando 35 primers, 10 revelaram polimorfismo para o cultivar "Sunhigh" e somente 1 revelou polimorfismo para um somaclone do cultivar "Redhaven".

Um marcador RAPD-especifico foi detectado por Damasco et al (1996), o qual permitiu a identificação de off-types. Esse marcador está associado à característica nanismo em plantas derivadas da micropropagação de banana (Musa spp. AAA). Nesta pesquisa, 59 plantas anãs foram identificadas a partir de diferentes eventos de micropagação. Os 66 primers utilizados, revelaram uma taxa de $28,8 \%$ de polimorfismo induzido. Foi encontrada, utilizando o primer OPJ-04, uma banda de 1500 bp presente 
consistentemente em todas as plantas normais e ausentes nas plantas anãs. Este marcador é uma ferramenta de extrema valia pois permite a detecção e eliminação das plantas anãs regeneradas por cultura de tecidos.

Em cana de açúcar os RAPDs foram utilizados na identificação de dois somaclones resistentes ao vírus do mosaico. As marcas diferenciam os somaclones resistentes quando comparados com a planta mãe que é susceptível (Oropeza et al., 1995).

Heinze \& Schmidt (1995) utilizaram marcadores RAPD para o monitoramento da fidelidade genética em plantas oriundas da embriogênese somática de Picea abies. Porém, não observaram modificações nos padrões de RAPD, quando compararam as linhagens celulares com as respectivas linhagens controle.

Rani et al. (1995) utilizaram a técnica do RAPD para detectar com precisão diferenças genéticas causadas pela micropropagação. Partiu-se de um clone de Populus deltoides e comparou-se o material in vitro com o material in vivo. Foram seleciondas da cultura in vitro 23 plantas e testados 11 primers dos quais 5 foram polimóficos (OPC-07, OPA-10, OPA-05, OPA-08 e OPC-19). Este estudo demostrou que o RAPD detectou polimorfismos gerados pela cultura de tecidos em plantas de $P$. deltoides. Estes novos locos presentes indicam que houve mudanças no sítio de anelamento.

Schneider \& Zyprian (1996) analisaram 47 plantas de Vitis vinifera regeneradas de protoplastos através de marcadores do tipo RAPD. Usando 60 primers, os autores observaram que 59 deles se apresentaram monomórficos. Apenas o primer OP0-11 mostrou ausência de uma banda de $1630 \mathrm{bp}$ em apenas dois clones. Para a confirmação do polimorfismo foi feito um Southern blot utilizando a banda polimórfica purificada como sonda.

Todoroviska et al., (1997) analisaram variantes somaclonais de plantas de cevada oriundas da cultura de calos através de marcadores RAPD. Este marcadores se mostraram polimórficos e estas marcas foram associadas a alterações em características agronômicas. Concluíram que os RAPDs são ferramentas importantes na detecção da variação somaclonal. 


\section{MATERIAL E MÉTODOS}

\subsection{Material vegetal}

Foram utilizadas duas variedades brasileiras de cana-de-açúcar: a variedade RB83-5486 e a SP80-185.

\subsubsection{Coleta de plantas de campo, oriundas da cultura de meristema}

Foram utilizadas inicialmente quatro plantas aberrantes, da variedade RB83-5486, coletadas na Usina Barra Grande, localizada em Lençóis Paulista - SP. Estas plantas passaram pela cultura de meristema em 1993 e se encontravam, na data da coleta, no segundo plantio da cana-soca. Foram coletadas quatro plantas com fenótipo anormal escolhidas ao acaso, as quais foram designadas por $M_{1}$ (Mutante 1), $M_{2}, M_{3}$ e $M_{4}$. Estes somaclones possuíam o colmo muito fino, excesso de gemas laterais; o $M_{1}$, superbrotamento das gemas laterais, $\circ \mathrm{M}_{2}$ particularmente, mostrava excesso de calosidades nos internós (Figura 1). Para verificar a existência da variação intraclone, esta população foi reamostrada e 48 plantas foram coletadas e comparadas com 48 plantas desta mesma variedade propagadas via colmos.

Num experimento posterior, foram analisadas plantas coletadas no campo da Usina Estér, localizada em Cosmópolis - SP, provenientes de dez meristemas da variedade RB83-5486, em cinco repicagens, num total de 50 plantas. 


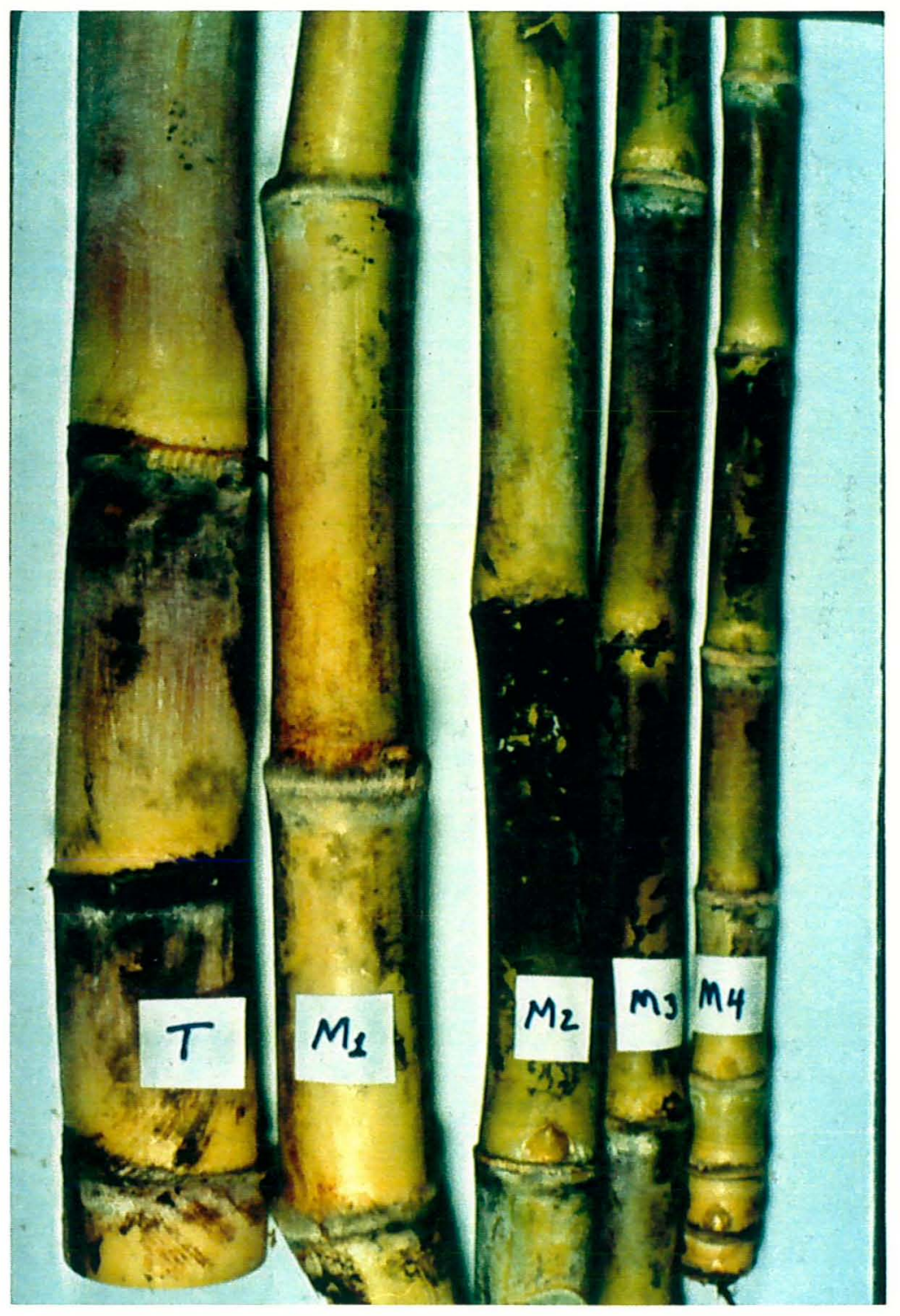

Figura 1. Plantas de cana-de-açúcar da variedade RB83-5486, propagadas via cultura de meristema, mostrando o caule da planta mãe $(T)$ ao lado dos somaclones designados por $M_{1}$ (Mutante 1), $M_{2}, M_{3}$ e $M_{4}$. 


\subsubsection{Coleta de plântulas cultivadas in vitro}

Foram analisadas plantas in vitro seguindo a sua descendência, com a finalidade de verificar a variação gerada in vitro a partir da planta mãe, doadora de meristema e dos ancestrais conhecidos em cada repicagem. Foram analisadas duas variedades: a RB83-5486 que apresenta problemas de variação somaclonal e, como controle, a SP80-185, uma variedade modelo na cultura de tecidos de cana-de-açúcar. Foram analisadas 30 plantas de cada variedade, partindo-se de cinco meristemas/variedade/seis fases de repicagem. Este experimento foi realizado no CTC.

\subsection{Extração do DNA genômico}

Tanto o material de campo quanto o material oriundo da cultura in vitro, foi coletado e conservado sobre gelo e rapidamente processado para a extração de DNA.

Para extração de DNA utilizou-se o método do CTAB descrito por Murray \& Thompson (1980) e Rogers \& Bendich (1985), com modificações. Foram utilizados, aproximadamente, $250 \mathrm{mg}$ de tecido fresco de cada planta, que foram macerados em nitrogênio liquido. Após a maceração, o material foi transferido para tubos eppendorf de $2 \mathrm{~mL}$, contendo $1 \mathrm{~mL}$ do tampão de extração (100 mM Tris- $\mathrm{HCl}$ pH 8,0; 1,4 M NaCl; 20 mM EDTA; $2 \%$ (p/v) CTAB, $1 \%(p / v)$ PVP 40.000) ao qual foi adicionado $1 \% \beta$-mercaptoetanol, previamente aquecido a $65^{\circ} \mathrm{C}$. O material foi homogeneizado com uma espátula e mantido a $65^{\circ} \mathrm{C}$ por $30 \mathrm{~min}$, em banho-maria, com agitações periódicas; após a retirada dos tubos do banho-maria, acrescentou-se uma mistura de $700 \mu \mathrm{L}$ de clorofórmio-octanol (24:1), homogeneizando-se por inversões dos tubos.

As amostras foram centrifugadas por $15 \mathrm{~min}$ a $14.000 \mathrm{rpm}$ em microcentrifuga Eppendorf, recuperando $700 \mu \mathrm{L}$ do sobrenandante, ou fase 
aquosa, os quais foram transferidos para novos tubos de $2 \mathrm{~mL}$. Para a precipitação do DNA, acrescentou-se $520 \mu \mathrm{L}$ de isopropanol, invertendo-se cuidadosamente os tubos, que foram mantidos por $30 \mathrm{~min}$ à temperatura ambiente ou colocados sob refrigeração a $4^{\circ} \mathrm{C}$ para favorecer a precipitação do DNA. O precipitado foi recuperado através de centrifugação a 10.000 rpm durante $10 \mathrm{~min}$. O sobrenadante foi descartado e, em seguida, adicionou-se 1 $\mathrm{mL}$ de solução de lavagem (etanol $76 \%$, acetato de $\mathrm{NH}_{4} 10 \mathrm{mM}$ ), por $30 \mathrm{~min}$. A solução de lavagem foi descartada e os tubos foram secos com cotonetes. Acrescentou-se $100 \mu \mathrm{L}$ de solução TE (10 mM Tris- $\mathrm{HCl}$ pH 8,0; $1 \mathrm{mM}$ EDTA pH $8,0)$ aos tubos eppendorf, os quais permaneceram à temperatura de aproximadamente $4^{\circ} \mathrm{C}$ por cerca de $16 \mathrm{~h}$ para a ressuspensão do DNA. O DNA foi novamente precipitado acrescentando-se $50 \mu \mathrm{L}$ de acetato de $\mathrm{NH}_{4} 7,5 \mathrm{M}$ e $375 \mu \mathrm{L}$ de etanol absoluto. O conteúdo do tubo foi misturado por inversões e o DNA foi recuperado por centrifugação por $20 \mathrm{~min}$ a $10.000 \mathrm{rpm}$. 0 sobrenadante foi descartado e a última lavagem foi feita adicionando-se $500 \mu \mathrm{L}$ de etanol $70 \%$ por $20 \mathrm{~min}$. O etanol foi descartado e os resíduos foram eliminados passando-se cotonetes na parede dos tubos. Ao DNA foram acrescentados cerca de $100 \mu \mathrm{L}$ de TE.

\subsection{Quantificação do DNA}

A quantificação foi realizada em géis de agarose $0,8 \%(p / v)$ submetidos à eletroforese. Alíquotas de cada DNA foram aplicadas nos poços do gel ao lado de uma série de concentações conhecidas de DNA do fago $\lambda$ (20 a $400 \mathrm{ng}$ ). A concentração das amostras foi estimada por comparação visual da intensidade de fluorescência das bandas do DNA do fago $\lambda$. Os géis foram visualizados após a coloração com $10 \mu \mathrm{L}$ de brometo de etídeo $(10 \mathrm{mg} / \mathrm{mL})$ diluído em $100 \mathrm{~mL}$ de tampão TEB 1X. Posteriormente o DNA foi diluído (5 $\mathrm{ng} / \mu \mathrm{L})$ para as reações de RAPD. 


\subsection{Condições de Amplificação}

Após a quantificação do DNA, as reações de amplificação foram feitas em termociclador modelo TC01 da Perkin Elmer-Cetus, de acordo com as condições descritas por Vieira et al. (1997), com modificações. As reações foram feitas em volume de $25 \mu \mathrm{L}$ contendo: $10 \mathrm{mM}$ Tris- $\mathrm{HCl} \mathrm{pH} \mathrm{8,3;50} \mathrm{mM} \mathrm{de}$ $\mathrm{KCl} ; 2,0 \mathrm{mM} \mathrm{MgCl}_{2} ; 0,2 \mathrm{mM}$ dNTPs; 0,25 $\mu \mathrm{M}$ de primer (Operon Technologies), 20 e $40 \mathrm{ng}$ de DNA molde, 2 unidades de Taq polimerase e $\mathrm{H}_{2} \mathrm{O}$ q.s.p.. As reações foram submetidas a 40 ciclos de amplificação após desnaturação inicial a $92^{\circ} \mathrm{C}$ por $4 \mathrm{~min}$. Cada ciclo consistiu de $45 \mathrm{seg}$ a $92^{\circ} \mathrm{C}, 1 \mathrm{~min}: 30 \mathrm{seg}$ a $40^{\circ} \mathrm{C}$ e $1 \mathrm{~min}: 30 \mathrm{seg}$ a $72^{\circ} \mathrm{C}$. Ao final de 40 ciclos, foi realizada uma extensão final de 5 $\min a 72^{\circ} \mathrm{C}$.

Os produtos de amplificação foram submetidos à eletroforese $(3 \mathrm{~V} / \mathrm{cm})$ em géis de agarose $1,4 \%(\mathrm{p} / \mathrm{v})$, utilizando o tampão de corrida TEB $1 \mathrm{X}$. Ladder 100bp (Gibco) foi usado como marcador de peso molecular. Os géis foram corados com brometo de etídio e fotografados sob luz UV (GEL.DOC 2.000 - Bio Rad).

\subsection{Análise dos dados Moleculares}

A análise dos dados moleculares foi realizada a partir da leitura dos géis, calculando-se as taxas de polimorfismo, comparando-se as plantas derivadas da cultura de meristema com as plantas testemunhas. 


\subsection{Análise preliminar}

\subsubsection{Seleção de primers}

Os primers foram selecionados fazendo-se um screening inicial com cinco plantas ( $M_{1}, M_{2}, M_{3} \in M_{4}$, juntamente com a testemunha). Para isto, utilizou-se 20 primers do Kit $A$; posteriormente também foram utilizados três primers do Kit $\mathrm{E}$ e dois do Kit $\mathrm{F}$ (Operon Technologies). Foram avaliados um total de 98 locos e foi calculada a taxa de polimorfismo. Este experimento teve a finalidade de fazer um screening de primers polimórficos para serem usados nos experimentos posteriores. Este experimento foi posteriormente repetido usando-se cinco plantas mutantes.

\subsubsection{Variação intraclone}

Neste experimento, foram analisadas 48 plantas aberrantes (Figuras 2 e 3), coletadas na usina Barra Grande e 48 plantas que não passaram ela cultura de tecidos; foram testados 98 locos. Foram calculadas as taxas de polimorfismo entre nas duas populações, com a finalidade de confirmar se a taxa de polimorfismo ao nível de DNA é realmente aumentada nas plantas oriundas da cultura de tecidos.

\subsection{Análise de plantas micropropagadas}

\subsubsection{Coletadas no campo experimental}

Foram analisadas plantas da variedade RB83-5486 coletadas no 
campo da Usina Estér, localizada em Cosmópolis, provenientes de dez meristemas $\left(\mathrm{Me}_{1}, \mathrm{Me}_{2}, \mathrm{Me}_{3} \ldots .\right.$. e $\left.\mathrm{Me}_{10}\right)$ /cinco repicagens, num total de 50 plantas. A cada repicagem uma amostra de mudas foi retirada do cultivo in vitro, aclimatada e transplantada para o campo para posterior análise. Foram avaliados um total de 98 locos e foi calculada a taxa de polimorfismo. Este experimento teve a finalidade de demonstrar se havia um incremento de variabilidade com o aumento do número de repicagens. 


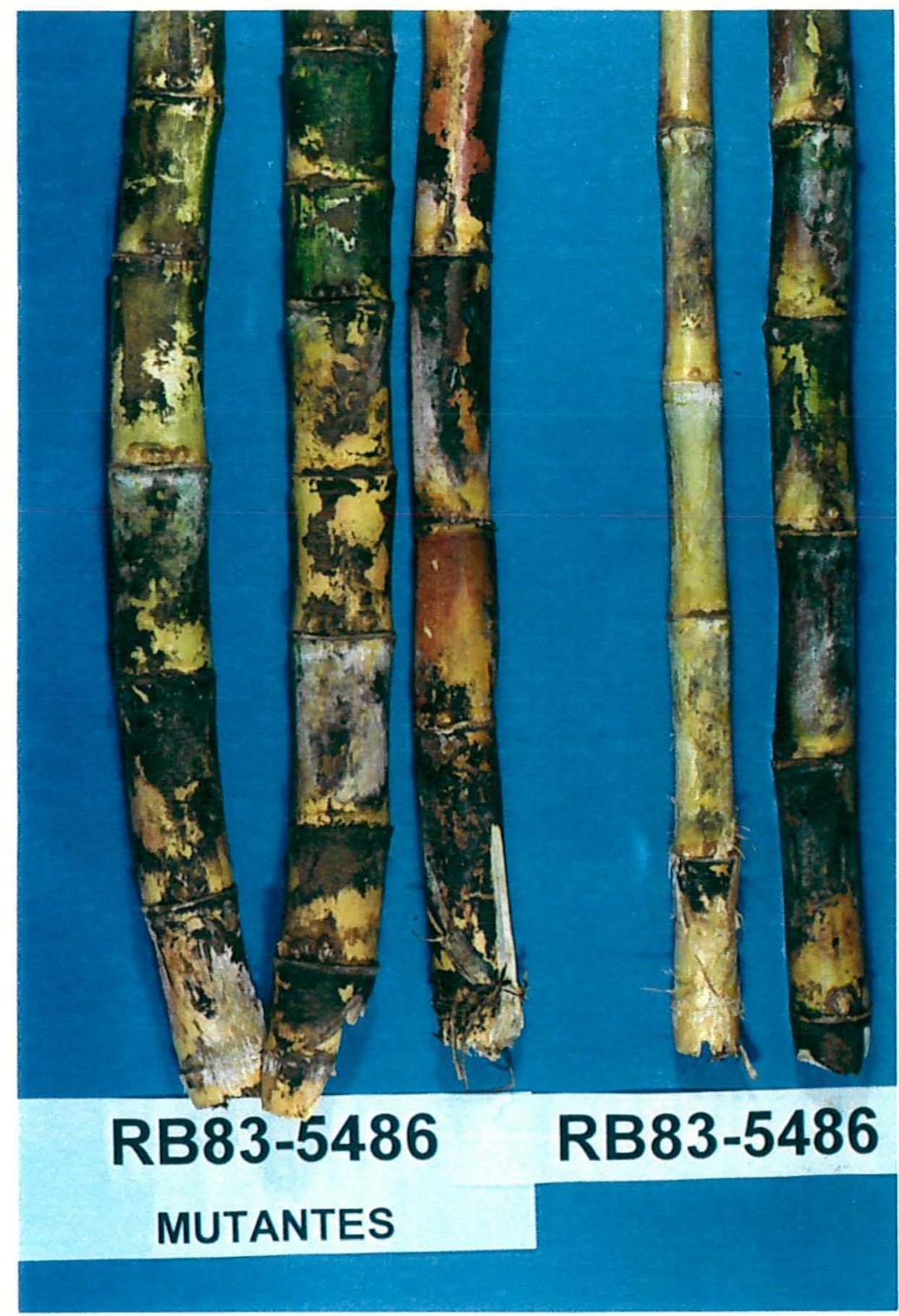

Figura 2. Plantas de cana-de-açúcar da variedade RB83-5486, propagadas via cultura de meristema, mostrando à esquerda, plantas com caule anormal, ao lado de plantas normais. 

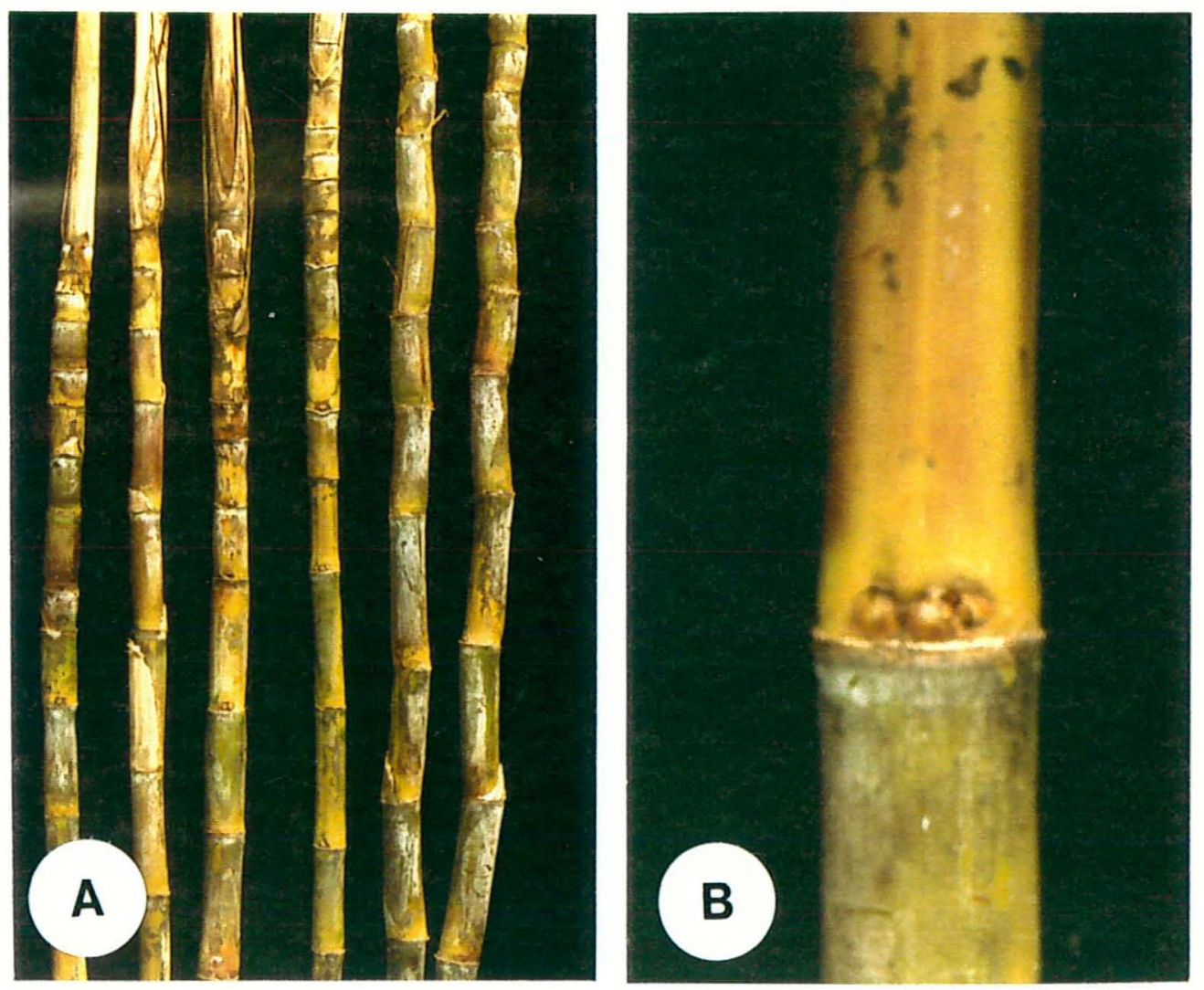

Figura 3. Plantas da variedade RB83-5486, propagadas via cultura de meristema, mostrando as principais características afetadas, como calosidade, achatamento nos colmos (a) e gemas múltiplas (b). 


\subsubsection{Coletadas da cultura in vitro}

A cultura in vitro iniciou-se a partir de dez perfilhos de canas de diferentes touceiras da variedade RB83-5486, plantadas no jardim varietal do CTC, de plantas que foram multiplicadas por propagação vegetativa via colmos. Uma gema de cada um destes perfilhos foi plantada em casa de vegetação sobre um substrato (tortilha de filtro e terra). Quando os brotos recémgerminados atingiram cerca de $30 \mathrm{~cm}$ de altura, foram coletados os "palmitos" para a retirada do meristema. Estes palmitos foram levados para o laborátorio e a sua desinfestação foi feita com hipoclorito de cálcio $2 \%$, por 20 min. A partir da desinfestação, o manuseio foi efetuado em câmara de fluxo laminar, onde o meristema foi desencapado até atingir o tamanho de 0,2 a $0,5 \mathrm{~cm}$ de comprimento. Este meristema foi colocado em um meio denominado fase 1 (fase de crescimento do meristema) por aproximadamente um mês, até atingir cerca de $2 \mathrm{~cm}$ de comprimento; posteriormente foi transferido para o meio denominado fase 2 (fase de multiplicação), sendo feitas então aproximadamente cinco repicagens; a cada repicagem fez-se o desmembramento das touceiras, gerando em média dez plântulas; finalmente estas foram transferidas para o meio fase 3 (meio de enraizamento), no qual as plantas foram cultivadas por aproximadamente um mês.

Como controle, foi usada a variedade SP80-185, que é considerada modelo na cultura de tecidos de cana-de-açúcar.

A amostragem do material in vitro, iniciou-se após o desenvolvimento do meristema com cerca de $2 \mathrm{~cm}$ (final da fase 1). Após ter-se retirado a parte aérea para análise molecular, estes meristemas seguiram para a primeira repicagem (fase 2). Durante as repicagens foi escolhida, ao acaso, uma plântula da qual foi retirada a parte aérea para análise molecular e novamente esta plântula seguiu para a geração de novas plântulas in vitro para a próxima repicagem. Este processo foi repetido até a sexta repicagem. Deste modo, foi possível analisar a descendência do cultivo in vitro.

Foram analisadas 30 plantas de cada variedade, partindo de cinco 
meristemas/variedade/seis fases de repicagens, juntamente com o meristema e a planta doadora de meristema. Foram avaliados um total de 98 locos e foi calculada a taxa de polimorfismo.

As plantas geradas a cada repicagem da cultura de tecidos que não foram analisadas, foram descartadas.

O meio básico usado nas três fases foi o MS (Murashige \& Skoog, 1962), acrescido de $20 \mathrm{~g} / \mathrm{L}$ de sacarose e vitaminas e hormônios como decrito na Tabela 1.

Tabela 1. Suplementação de compostos orgânicos e de fitorreguladores para 0 cultivo de cana-de-açúcar em meio basal MS, conforme a fase do cultivo (em $\mathrm{mg} / \mathrm{L}$ ).

\begin{tabular}{cccc}
\hline Composto/fase & Fase 1 & Fase 2 & Fase 3 \\
\hline Tiamina & 0,1 & 0,1 & 0,1 \\
Inositol & 10,0 & 10,0 & 10,0 \\
Cinetina & - & 0,01 & 0,01 \\
BA & - & 0,02 & - \\
IBA & 0,001 & - & 0,2 \\
GA $_{3}$ & 0,01 & - & - \\
\hline
\end{tabular}




\section{RESULTADOS E DISCUSSÃO}

\subsection{Análise preliminar}

A exemplo de Burner \& Grisham (1995) que verificaram variações fenotípicas em plantas de cana-de-açúcar da variedade CP74-383 oriundas da cultura de tecidos, tais como: diâmetro fino do colmo, rachadura nos internós e anormalidades nas gemas axilares com superbrotação prematura, neste trabalho observou-se variações fenótipicas semelhantes em plantas da variedade RB83-5486. Estas variações também foram observadas por Irvine (1984) e Irvine et al. (1991) em outras variedades de plantas micropropagadas de cana-de-açúcar.

\subsubsection{Seleção de primers}

Após a otimização das condições de reação, foi feita uma seleção entre 20 primers referentes ao kit $A$, dois primers do kit $F$ e três primers do kit $E$. Destes oligonucleotídeos foram selecionados nove com base no seu padrão de amplificação.

Este primeiro screening foi feito para verificar se havia diferença nos perfis de RAPD das plantas alteradas fenotipicamente $\left(M_{1}, M_{2}, M_{3}\right.$ e $\left.M_{4}\right)$ em relação às testemunhas ( Figura 4). 


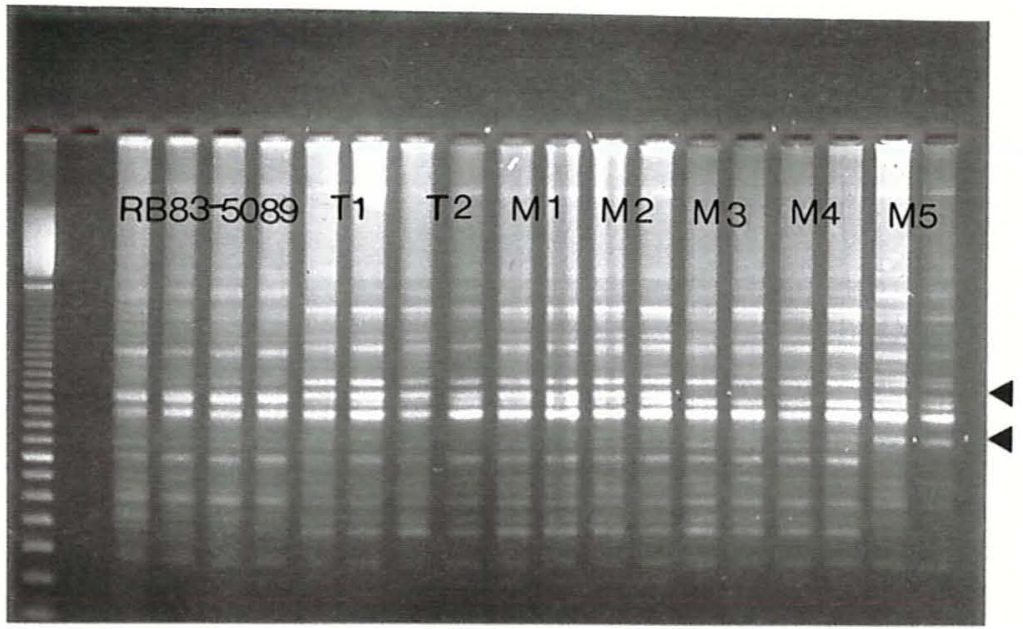

Figura 4. Perfil de RAPD para 9 plantas de cana-de-açúcar: 2 da variedade RB83-5089 e 7 da variedade RB83-5486, 2 plantas testemunhas e 5 morfologicamente alteradas $\left(M_{1}, M_{2}, M_{3}, M_{4}\right.$ e $\left.M_{5}\right)$, analisadas com o primer OPA08 , mostrando polimorfismo em $M_{2}, M_{3}$ e $M_{5}$. As amplificações foram feitas a partir de duas concentrações de DNA, 20 e 40 ng. À esquerda está o marcador de peso molecular (Ladder $100 \mathrm{bp}$ ). 
Dos 20 primers inicialmente testados, foram usados nove para 0 cálculo da taxa de polimorfismo.

Em um total de 98 locos, verificou-se que quatro mostraram-se polimórficos, que foram detectados pelos primers OPA-02 (um loco), OPA-04 (dois locos) e OPA-08 (um loco). Isto indica uma taxa de polimorfismo, induzido in vitro, da ordem de $4,08 \%$ (Tabela 2 ).

Tabela 2. Screening de primers polimórficos; usou-se quatro plantas testemunhas e quatro morfologicamente alteradas $\left(M_{1}, M_{2}, M_{3}\right.$ e $\left.M_{4}\right)$.

\begin{tabular}{lll}
\hline Primers & $\begin{array}{c}\text { Sequência de } \\
\text { bases }\end{array}$ & Número de locos * \\
\hline OPA-01 & CAGGCCCTTC & 09 \\
OPA-02 & TGCCGAGCTG & $10(1)$ \\
OPA-03 & AGTCAGCCAC & 11 \\
OPA-04 & AATCGGGCTG & $14(2)$ \\
OPA-07 & GAAACGGGTG & 10 \\
OPA-08 & GTGACGTAGG & $15(1)$ \\
OPA-09 & GGGTAACGCC & 08 \\
OPA-10 & GTGATCGCAG & 09 \\
OPA-16 & AGCCAGCGAA & 12 \\
\hline
\end{tabular}

* Entre parênteses está indicado o número de locos polimórficos

Em seguida ao experimento de screening de primers, este foi repetido, incluindo-se na análise cinco variantes somaclonais $\left(M_{1}, M_{2}, M_{3}, M_{4}\right.$ e $M_{5}$ ) além das quatro plantas usadas como testemunha. Neste caso foram usados 11 primers que geraram 98 locos, dos quais sete mostraram-se polimórficos, indicando uma taxa de polimorfismo da ordem de $7,14 \%$. 
Tabela 3. Polimorfismo induzido pela cultura de tecidos; usou-se quatro plantas testemunhas e cinco morfologicamente alteradas $\left(M_{1}, M_{2}, M_{3}, M_{4}\right.$ e $\left.M_{5}\right)$.

\begin{tabular}{lll}
\hline Primers & $\begin{array}{c}\text { Sequência de } \\
\text { bases }\end{array}$ & Número de locos * \\
\hline OPA-02 & TGCCGAGCTG & $10(1)$ \\
OPA-03 & AGTCAGCCAC & 11 \\
OPA-04 & AATCGGGCTG & $14(2)$ \\
OPA-07 & GAAACGGGTG & 10 \\
OPA-08 & GTGACGTAGG & $15(2)$ \\
OPA-09 & GGGTAACGCC & 08 \\
OPA-10 & GTGATCGCAG & $09(1)$ \\
OPA-13 & CAGCACCCAC & 13 \\
OPA-14 & TTCCGAACCC & 08 \\
OPA-16 & AGCCAGCGAA & $12(1)$ \\
OPA-20 & GTTGCGATCC & 08 \\
\hline
\end{tabular}

* Entre parênteses está indicado o número de locos polimórficos

Com o acréscimo de mais um variante somaclonal $\left(M_{5}\right)$, observouse um aumento do polimorfismo induzido de $4,08 \%$ (Tabela 2) para $7,14 \%$ (Tabela 3). Este aumento pode ser explicado provavelmente pela inclusão do variante $M_{5}$ na amostra.

\subsubsection{Variação intraclone}

A Tabela 4 apresenta resultados das análises de RAPD realizadas com a finalidade de verificar se há ocorrência de polimorfismo intrínseco em plantas de cana-de-açúcar que não passaram por cultura de tecidos 
(propagadas via colmos). Em 98 locos analisados a partir da amplificação do DNA de 48 plantas, foi encontrado apenas um loco polimórfico; isto indica que há na cana-de-açúcar uma taxa de polimorfismo intrínseco ao clone da ordem de $1,02 \%$. (Figura 5 )

Wallner et al. (1996) verificaram um alto grau de polimorfismo intraclones em plantas propagadas vegetativamente e também em plantas micropropagadas de 19 espécies de Achillea. Com 13 primers de microsatélites e 28 primers de RAPD foi possivel discriminar os membros do grupo de Achillea millefolium e seus clones micropropagados.

O alto nível de ploidia da cana-de-açúcar e a complexidade de seu genoma devem ser responsáveis pela variação intraclone observada neste estudo.

Tabela 4. Polimorfismo intraclone em cana-de-açúcar; foram utilizadas 48 plantas normais, propagadas via colmos.

\begin{tabular}{ccc}
\hline Primer & $\begin{array}{c}\text { Sequência de } \\
\text { bases }\end{array}$ & Número de locos * \\
\hline OPA-02 & TGCCGAGCTG & 10 \\
OPA-03 & AGTCAGCCAC & 11 \\
OPA-04 & AATCGGGCTG & $14(1)$ \\
OPA-08 & GTGACGTAGG & 15 \\
OPA-10 & GTGATCGCAG & 09 \\
OPA-16 & AGCCAGCGAA & 12 \\
OPA-18 & AGGTGACCGT & 12 \\
OPA-19 & CAAACGTCGG & 13 \\
OPA-20 & GTTGCGATCC & 8 \\
\hline
\end{tabular}

* Entre parênteses está indicado o número de locos polimórficos 
Na Tabela 5 são apresentados os resultados relativos à análise de 48 plantas oriundas da cultura de meristema. Em 98 locos analisados, sete mostraram-se polimórficos, indicando uma taxa de $7,14 \%$ de polimorfismo molecular, induzido pela cultura de tecidos (Figura 6).

Tabela 5. Polimorfismo induzido pela cultura de meristema; foram utilizadas 48 plantas anormais, micropropagadas.

\begin{tabular}{ccc}
\hline Primer & $\begin{array}{c}\text { Sequência de } \\
\text { bases }\end{array}$ & Número de locos * \\
OPA-02 & TGCCGAGCTG & $10(1)$ \\
OPA-03 & AGTCAGCCAC & 11 \\
OPA-04 & AATCGGGCTG & $14(2)$ \\
OPA-07 & GAAACGGGTG & 10 \\
OPA-08 & GTGACGTAGG & $15(2)$ \\
OPA-10 & GTGATCGCAG & 9 \\
OPA-16 & AGCCAGCGAA & 12 \\
OPA-18 & AGGTGACCGT & $12(2)$ \\
OPA-20 & GTTGCGATCC & 8 \\
\hline
\end{tabular}

* Entre parênteses está indicado o número de locos polimórficos

De fato, a cultura de tecidos foi responsável pelo incremento da variabilidade gerada, pois foi verificado um aumento nas taxas de polimorfismo molecular. Este incremento foi de cerca de 7,0 vezes.

Muitos são os fatores responsáveis pelo incremento da variabilidade nas plantas oriundas da cultura de meristema, entre eles: a metilação do DNA, a ploidia do explante, a interação genótipo $x$ meio de cultura, além de outros fatores que serão discutidos posteriormente. 

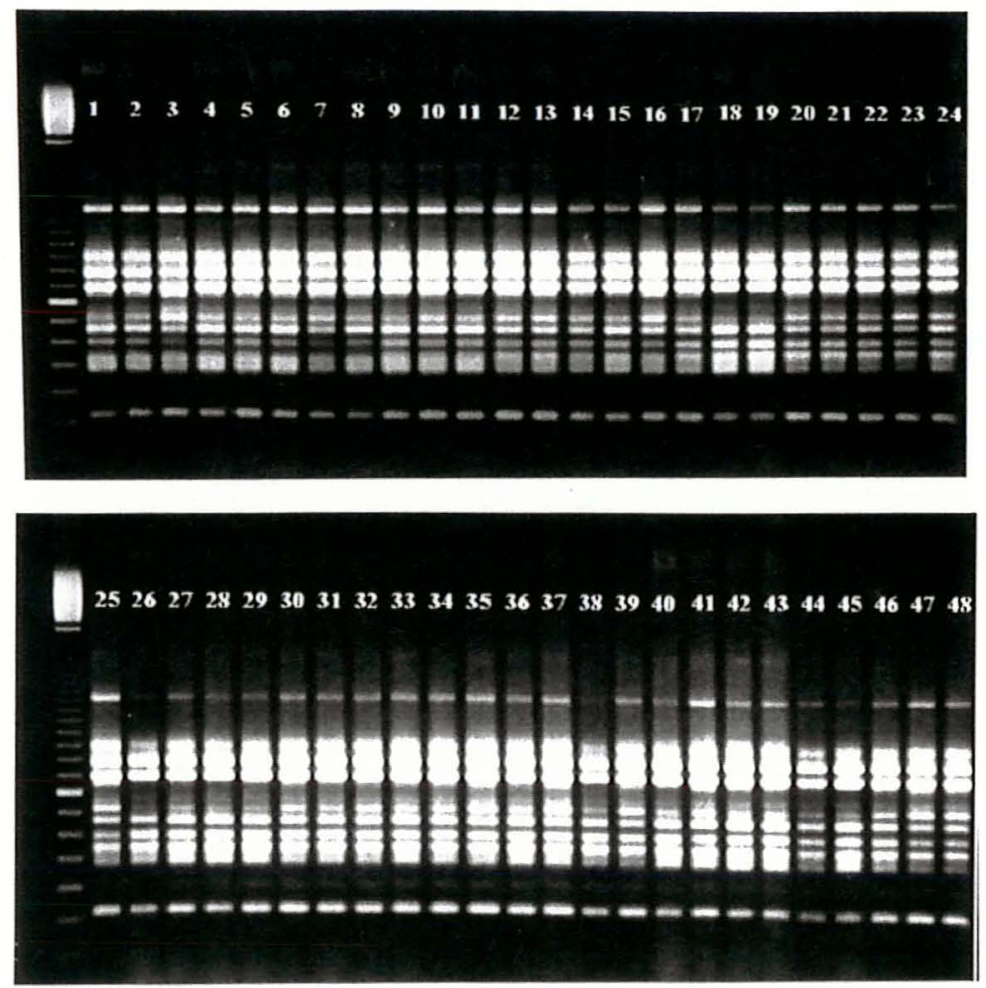

Figura 5. Perfil de RAPD para 48 plantas de cana-de-açúcar da variedade RB83-5486, que foram propagadas vegetativamente, analisadas com o primer OPA-02, mostrando monomorfismo entre os clones. À esquerda está o marcador de peso molecular (Ladder $100 \mathrm{bp}$ ). 

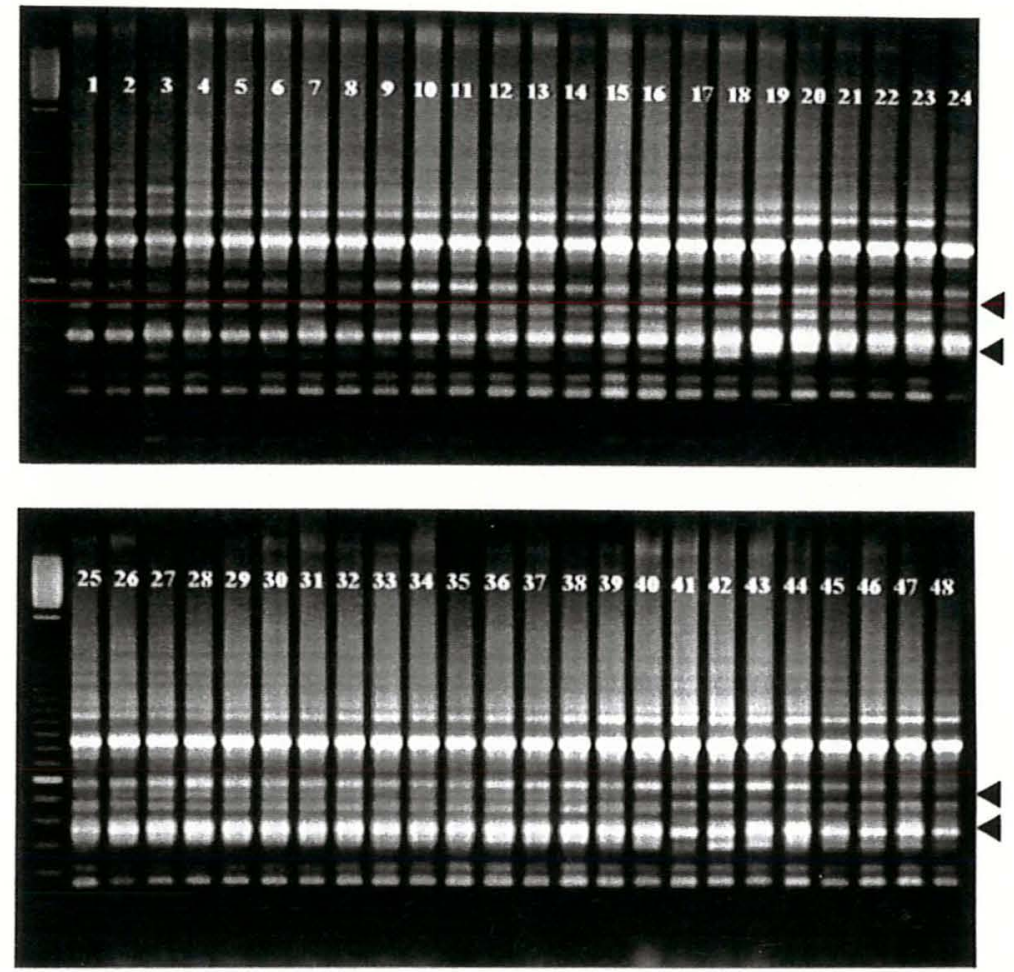

Figura 6. Perfil de RAPD para 48 plantas de cana-de-açúcar da variedade RB83-5486, propagadas pela cultura de meristema, analisadas com o primer OPA-18, mostrando polimorfismo entre os clones. $\dot{A}$ esquerda está o marcador de peso molecular (Ladder $100 \mathrm{bp}$ ). 
A ocorrência de variação intraclone pode estar associada à pequena porcentagem de variação molecular detectada neste estudo $(1,02 \%)$ e esta pode ser derivada de mutações de ponto ou aberrações cromossômicas naturais.

Foi verificado um pequeno nível de variação morfológica na propagação via colmos em plantas desta variedade de cana-de-açúcar $\left(\right.$ Arizono $^{1}$ ). Isto indica que essa variedade per se mostra variação e, quando propagada in vitro, esta variação tende a aumentar. É provável que esta variedade possua um genótipo instável e que necessite de um protocolo de micropropagação específico.

Como afirmado anteriormente, o fato da cana-de-açúcar ser uma espécie poliplóide (octoplóide) contribui para o surgimento da variação somaclonal. Devido à rápida multiplicação celular, induzida pela utilização de fitorreguladores, há maior possibilidade de ocorrência de aberrações cromossômicas (Fish \& Karp, 1986).

Existem muitos relatos na literatura de que a cana-de-açúcar possui um mosaicismo celular, existência de tecido com diferentes números de núcleos e isto explicaria parte da variação in vitro (Liu, 1984 e Meins Jr.,1983).

Heinz \& Mee (1971), trabalhando com cultura de calos de cana-deaçúcar, derivadas da variedade H50-7209, encontraram clones com mosaicismo cromossomal variando entre $2 n=94$ a 120 . Em contrapartida, estes autores analisaram outra variedade, a H37-1933, e encontraram estabilidade cromossômica $(2 n=106)$. Estes resultados nos levam a deduzir que existe realmente, interação genótipo $x$ meio de cultura, e que alguns genótipos são mais instáveis in vitro, sendo mais susceptíveis a variações.

A ocorrência de mixoploidia também foi verificada no cultivo in vitro da soja cujo número de cromossomos de uma célula normal é $2 n=40$. Após a cultura in vitro, foi verificado que o número de cromossomos variou entre 10 a 60 e isto explica a esterilidade total ou parcial de muitas plantas variantes (Berwale \& Widholm, 1990).

\footnotetext{
'Arizono, H. (Universidade Federal de São Carlos - Araras) Comunicação pessoal, 1996.
} 


\subsection{Análise de plantas de campo oriundas da cultura de meristema}

A Tabela 6 mostra os resultados da análise molecular de plantas micropropagadas, em desenvolvimento no campo da Usina Estér. Foram utilizados inicialmente quatro meristemas $\left(\mathrm{Me}_{1}, \mathrm{Me}_{2}, \mathrm{Me}_{3}\right.$ e $\left.\mathrm{Me}_{4}\right)$, nas cinco fases de repicagens, sendo estudadas 5 plantas/repicagem. Entre os 98 locos estudados, dez mostraram-se polimórficos. As taxas de polimorfismos foram de 0,0\% $\left(\mathrm{Me}_{1}\right), 5,1 \%\left(\mathrm{Me}_{2}\right), 2,04 \%\left(\mathrm{Me}_{3}\right)$, e 3,06\% $\left(\mathrm{Me}_{4}\right)$. Não foram observados locos preferencialmente polimórficos.

Tabela 6. Polimorfismo molecular em plantas de cana-de-açúcar coletadas no campo, derivadas da cultura de meristema. Foram analisadas 20 plantas provenientes de quatro meristemas $\left(\mathrm{Me}_{1}, \mathrm{Me}_{2}, \mathrm{Me}_{3}\right.$ e $\left.\mathrm{Me}_{4}\right)$, em cinco fases de repicagem.

\begin{tabular}{llclll}
\hline Primers & $\begin{array}{c}\text { Sequência de } \\
\text { bases }\end{array}$ & \multicolumn{5}{c}{ Número de locos * } \\
& & $\mathrm{Me}_{1}$ & $\mathrm{Me}_{2}$ & $\mathrm{Me}_{3}$ & $\mathrm{Me}_{4}$ \\
OPA-02 & TGCCGAGCTG & 10 & $10(3)$ & 10 & $10(1)$ \\
OPA-03 & AGTCAGCCAC & 11 & 11 & $11(2)$ & 11 \\
OPA-04 & AATCGGGCTG & 14 & $14(1)$ & 14 & $14(1)$ \\
OPA-08 & GTGACGTAGG & 15 & 15 & 15 & $15(1)$ \\
OPA-10 & GTGATCGCAG & 09 & $09(1)$ & 09 & 09 \\
OPA-13 & CAGCACCCAC & 13 & 13 & 13 & 13 \\
OPA-16 & AGCCAGCGAA & 12 & 12 & 12 & 12 \\
OPA-18 & AGGTGACCGT & 12 & 12 & 12 & 12 \\
OPA-20 & GTTGCGATCC & 08 & 08 & 08 & 08 \\
\hline
\end{tabular}

* Entre parênteses está indicado o número de locos polimórficos 
A tabelas 7 e 8 são idênticas à tabela 6 e se referem à análise molecular das plantas oriundas dos meristemas $\mathrm{Me}_{5}, \mathrm{Me}_{6}, \mathrm{Me}_{7}$ e $\mathrm{Me}_{8}$, e dos meristemas $\mathrm{Me}_{9}$ e $\mathrm{Me}_{10}$, respectivamente. As taxas de polimorfismos calculadas foram 3,06\% (Mes), 5,10\% $\left(\mathrm{Me}_{6}\right), 3,06 \%\left(\mathrm{Me}_{7}\right), 4,08 \%\left(\mathrm{Me}_{8}\right), 3,06 \%\left(\mathrm{Me}_{9}\right)$ e $4,08 \%\left(\mathrm{Me}_{10}\right)$.

Tabela 7. Polimorfismo molecular em plantas de cana-de-açúcar coletadas no campo, derivadas da cultura de meristema. Foram analisadas 20 plantas provenientes de quatro meristemas. (Me $\mathrm{Me}_{5}, \mathrm{Me}_{6}, \mathrm{Me}_{7} \mathrm{e} \mathrm{Me}_{8}$ ), nas 5 fases de repicagem.

\begin{tabular}{llllll}
\hline Primers & $\begin{array}{c}\text { Sequência de } \\
\text { bases }\end{array}$ & \multicolumn{5}{c}{ Número de locos * } \\
& & $M_{5}$ & $M_{6}$ & $\mathrm{Me}_{7}$ & $\mathrm{Me}_{8}$ \\
OPA-02 & TGCCGAGCTG & $10(2)$ & $10(1)$ & $10(1)$ & $10(1)$ \\
OPA-03 & AGTCAGCCAC & 11 & $11(1)$ & $11(2)$ & $11(1)$ \\
OPA-07 & GAAACGGGTG & 10 & 10 & 10 & 10 \\
OPA-08 & GTGACGTAGG & $15(1)$ & $15(1)$ & 15 & $15(1)$ \\
OPA-10 & GTGATCGCAG & 09 & 09 & 09 & 09 \\
OPA-12 & TCGGCGATAG & 08 & 08 & 08 & 08 \\
OPA-16 & AGCCAGCGAA & 12 & 12 & 12 & 12 \\
OPA-18 & AGGTGACCGT & 12 & 12 & 12 & $12(1)$ \\
OPE-05 & TCAGGGAGGT & 06 & $06(2)$ & 06 & 06 \\
OPE-06 & AAGACCCCTC & 10 & 10 & 10 & 10 \\
\hline
\end{tabular}

\footnotetext{
* Entre parênteses está indicado o número de locos polimórficos
} 
Tabela 8 . Polimorfismo molecular em plantas de cana-de-açúcar coletadas no campo, derivadas da cultura de meristema. Foram analisadas 10 plantas provenientes de dois meristemas $\left(\mathrm{Me}_{9}\right.$ e $\left.\mathrm{Me}_{10}\right)$, em cinco fases de repicagem.

\begin{tabular}{llll}
\hline Primers & $\begin{array}{c}\text { Sequência de } \\
\text { bases }\end{array}$ & \multicolumn{2}{c}{ Número de locos * } \\
\hline & & Meg $_{9}$ & Me $_{10}$ \\
OPA-02 & TGCCGAGCTG & $10(1)$ & $10(1)$ \\
OPA-03 & AGTCAGCCAC & 11 & $11(1)$ \\
OPA-07 & GAAACGGGTG & 10 & 10 \\
OPA-08 & GTGACGTAGG & $15(2)$ & $15(1)$ \\
OPA-09 & GGGTAACGCC & 08 & 08 \\
OPA-10 & GTGATCGCAG & 09 & 09 \\
OPA-12 & TCGGCGATAG & 11 & 11 \\
OPA-16 & AGCCAGCGAA & 12 & $12(1)$ \\
OPA-18 & AGGTGACCGT & 12 & 12 \\
\hline
\end{tabular}

* Entre parênteses está indicado o número de locos polimórficos 

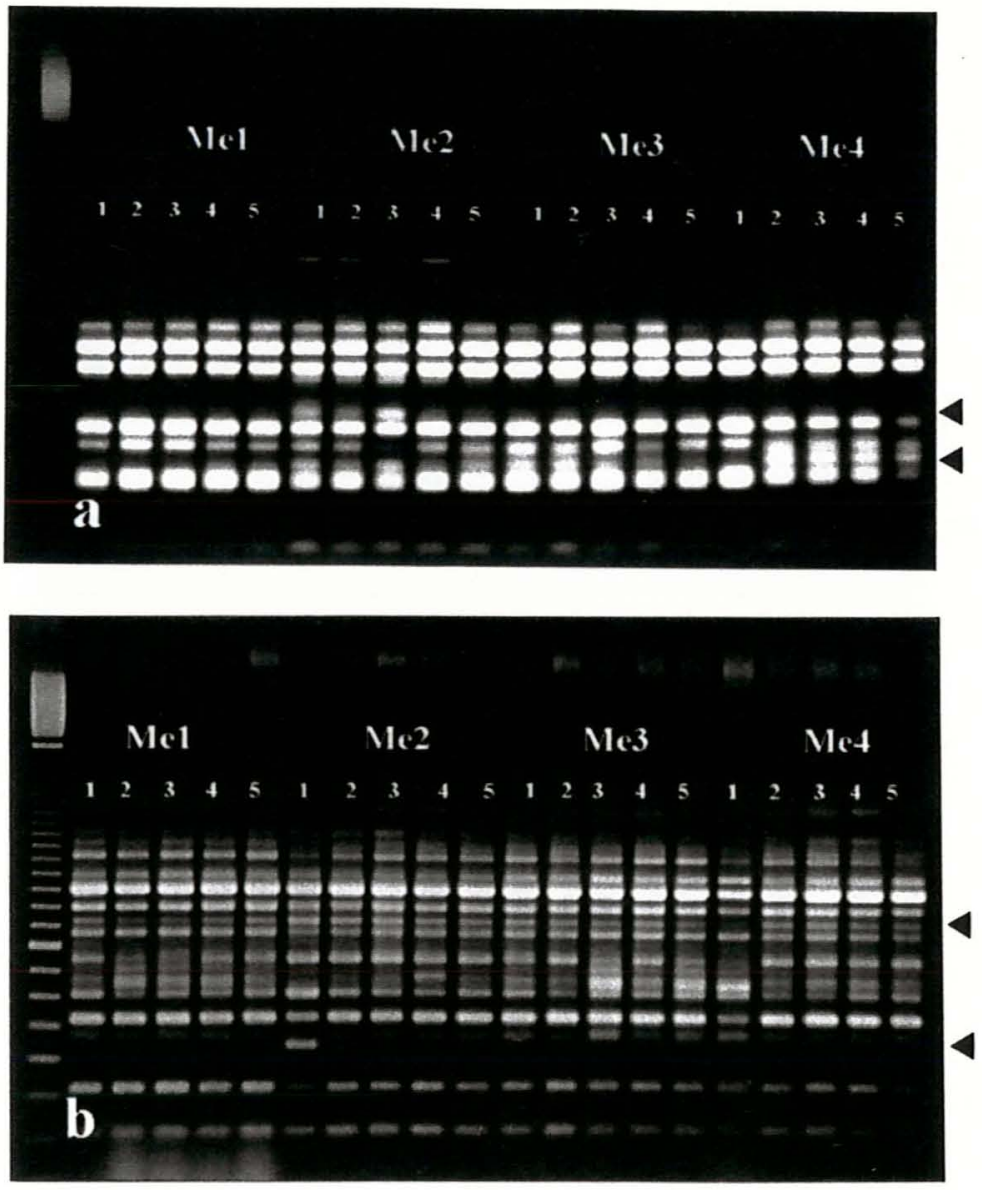

Figura 7. Perfil de RAPD de 20 plantas de cana-de-açúcar da variedade RB83-5486, provenientes de quatro meristemas $\left(\mathrm{Me}_{1}, \mathrm{Me}_{2}, \mathrm{Me}_{3}\right.$ e $\left.\mathrm{Me}_{4}\right)$ nas cinco fases de repicagens $(1,2,3,4$ e 5); primer OPA-02 (a) e OPA-04 (b), ambos perfis mostrando polimorfismo entre as repicagens. À esquerda está o marcador de peso molecular (Ladder $100 \mathrm{bp}$ ). 
Num total de 980 locos analisados, referentes a 50 plantas de canade-açúcar provenientes de dez meristemas em cinco fases de repicagens, foram detectados 32 locos polimórficos. Considerando-se os dez meristemas, a taxa média de polimorfismos, foi de $3,17 \%$, com um desvio padrão de 1,57. Estes polimorfismos ocorreram em todas as repicagens e não aumentaram com - número de subcultivos (figura 8 ). Observou-se na primeira repicagem um maior número de locos polimórficos. Pode-se supor que a introdução do meristema in vitro seja a fase mais estressante ao genoma. $O$ estresse in vitro pode levar o genoma a responder de maneira imediata, metilando o DNA.

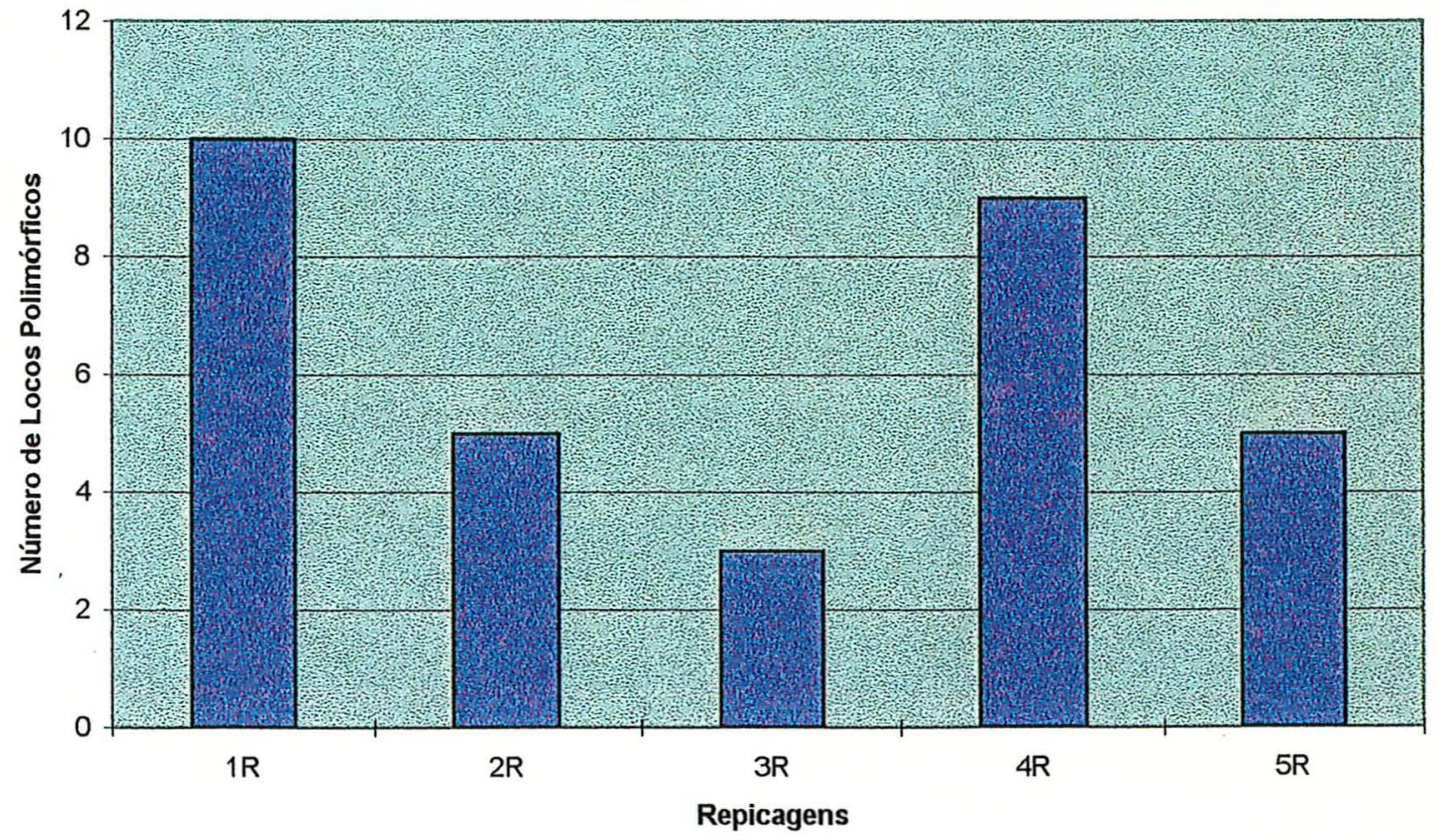

Figura 8. Número de locos polimórficos detectados em cada repicagem, considerando-se 50 plantas coletadas no campo, provenientes de dez meristemas. 
Meyer et al. (1992), estudaram cerca de 3.000 plantas transgênicas de petúnia contendo o gene $A 1$ que codifica a dihidroxiflavonol redutase, reponsável pela coloração salmão das flores. Foram analisadas quanto ao desenvolvimento e mostraram fenótipos variados: flores com fraca pigmentação ou flores brancas. Foram feitos testes moleculares e verificou-se a presença de metilação induzida pelo estresse ambiental, no sítio promotor.

As plantas estão sujeitas à numerosos estresses ambientais os quais podem induzir mudanças genéticas e epigenéticas, tanto quanto podem gerar maior variabilidade no seu genoma. Kovarik et al. (1997) analisou o DNA metilado de dois locos heterocromáticos com sequências de DNA repetitivo (HRS60 e GRS) em células de fumo, em resposta ao estresse a $\mathrm{NaCl}$ e manitol. Verificou-se, através da análise molecular com enzimas de restrição (isoesquisômeros $\mathrm{Mspl} / \mathrm{Hpall}$ e $\mathrm{Mbol} / \mathrm{Sau} 3 \mathrm{Al}$ ), a hipermetilação das citosinas destes locos heterocromáticos devido ao estresse. Existem evidências que a hipermetilação desta sequências é reversível.

Kovarik et al. (1997) sugerem que mudanças epigenéticas ao nível de DNA metilado tem um papel importante no mecanismo adaptativo ao estresse ambiental. Estresses ambientais também foram estudados na indução de variabilidade em plantas de linho, que mostraram mudanças rápidas e herdáveis no genoma.

Polimorfismos em sequências repetitivas do DNA têm sido frequentemente observados durante a propagação de plantas por cultura de tecidos (Smulders et al., 1995). Essas mudanças ocorrem devido ao estresse do cultivo in vitro.

Quando hipermetilado, o DNA provoca a inatividade gênica (Matzke \& Matzke, 1991) e a hipometilação em sítios específicos, tende a aumentar a atividade transcricional.

Em plantas, a hipometilação tem sido associada a numerosas mudanças no fenótipo, como por exemplo: o início do florescimento (Ronemus et al.,1996) e nanismo (Sano et al.,1990).

A presença de ilhas ricas em CpG na região 5' de alguns genes 
está associada ao efeito da metilação na expressão gênica. Essas ilhas são detectadas pela presença ou aumento da densidade de sequências CpG. Essas ilhas têm aproximadamente $1,2 \mathrm{~kb}$ e estão presentes em número de 30.000 aproximadamente, no genoma de mamíferos. Os trinucleotídeos $\mathrm{CpG}$ não estão metilados pois os nucleossomos têm poucas histonas $\mathrm{H} 1, e$ as outras histonas se encontram exclusivamente acetiladas (regiões associadas à expressão gênica) e são sítios hipersensíveis, indicando serem regiões promotoras. Essas ilhas podem ser alvo de metilação durante o cultivo in vitro (Lewin, 1994).

As instabilidades cromossomais mitóticas observadas em canade-açúcar são devidas à complexidade do seu genoma. Atualmente, os cultivares são descritos como aneuplóides interespecíficos com número de cromossomos variando entre $2 n=100$ a 130 (Sreenivasan et al., 1987). Estes fatos podem estar associados à predisposição à variação somaclonal observada neste trabalho.

O genoma de plantas superiores possue cerca de 95\% de DNA repetitivo e somente $5 \%$ de DNA codante. Dentro destas sequências, estão as regiões satélite (incluindo regiões de DNA altamente repetitivo em tandem) de DNA, sequências minisatélites e microsatélites (regiões de DNA moderadamente repetitivo em tandem) e elementos transponíveis (sequências móveis de DNA moderadamente repetitivas dispersas no genoma). Estas sequências são conhecidas pela sua alta capacidade de se multiplicar no genoma. Estão sujeitas a mutações devido a inserções de elementos transponiveis, rearranjos cromossômicos devido à recombinação entre sequências repetitivas ou às amplificações de sequências microsatélites. (Charlesworth et al., 1994)

A técnica do RAPD, como o próprio nome diz, revela polimorfismo devido a amplificação ao acaso do DNA, pois se utilizam primers de sequências aleatórias que amplificam segmentos quaisquer no genoma. Sendo assim, a natureza da banda do RAPD é, possivelmente, em sua maioria, DNA repetitivo. Sabe-se que estas sequências sofrem uma alteração maior do que sequências codantes do genoma. O estresse in vitro pode provocar alterações em sítios 
preferenciais, como em DNAs repetitivos, ativando elementos transponíveis. Isto explicaria as mudanças nos padrões de RAPD e o aparecimento e desaparecimento de bandas durante as repicagens.

Outra possivel explicação para o polimorfismo encontrado é que pode estar havendo competição de primers nas reações de RAPD, tendo em vista a poliploidia da espécie. Entretanto, se assim fosse, esta instabilidade estaria igualmente presente nas plantas testemunhas.

Além destes fatores, efeitos fisiológicos ou epigenéticos associados à metilação podem estar causando esta variação in vitro. Visto que, o estresse in vitro induz a metilação do DNA (Brown et al., 1991), como discutido anteriormente.

Podem ocorrer alterações no padrão de RAPD devido ao não anelamento do primer por mutações de ponto, inserção e deleção de sequências repetitivas ou não e ainda de elementos de transposição.

As sequências repetitivas são alvos de alterações durante o cultivo in vitro. Existem hipóteses que explicam esta afirmação. A primeira hipótese é quanto à evolução destas sequências. O princípio geral deste modelo é que os grupos de unidade repetitiva são frequentemente amplificados, gerando um grande número de cópias idênticas, em tandem. Este modelo é conhecido como Replicação Saltatória (Lewin, 1994). Outra hipótese, é que em cultura de tecidos pela rápida multiplicação celular devido à ação dos meios de cultura, ricos em sais e fitorreguladores, o ciclo celular é ativado ocorrendo muitos erros na replicação destas sequências no genoma devido ao escorregamento (slippage) da enzima polimerase (Lewin, 1994).

\subsection{Análise de plântulas cultivadas in vitro}

A Tabela 9 apresenta os resultados relativos aos estudos com plantas cultivadas in vitro, feitos para verificar os níveis de polimorfismo molecular em plântulas micropropagadas e suas descendências, derivadas de 
diferentes meristemas. Foram analisados cinco meristemas da variedade SP80$185(1,2,38$ e 9) nas cinco fases de repicagem. Neste experimento, foram analisadas cinco plantas advindas dos respectivos meristemas. Em 98 locos de RAPD, foram encontrados sete locos polimórficos $(7,14 \%)$. As taxas de polimorfismo para os diferentes meristemas foram: $0,0 \%\left(\mathrm{Me}_{1}\right), 1,02 \%\left(\mathrm{Me}_{2}\right)$, 3,06\% ( $\left.\mathrm{Me}_{3}\right), 1,02 \%\left(\mathrm{Me}_{8}\right)$ e 1,02\% (Me $)$. A taxa média de polimorfismo foi de $1,23 \%$, com desvio padrão de 1,12 .

Tabela 9. Polimorfismo molecular em plântulas cultivadas in vitro. Foram analisadas 30 plântulas oriundas de cinco meristemas retirados da variedade SP80-185.

\begin{tabular}{llccccc}
\hline Primers & $\begin{array}{c}\text { Sequência de } \\
\text { bases }\end{array}$ & \multicolumn{6}{c}{ Número de locos * } \\
\hline & & $M_{1}$ & $M_{2}$ & $M_{3}$ & $M_{8}$ & $M_{9}$ \\
OPA-02 & TGCCGAGCTG & 11 & 11 & 11 & 11 & 11 \\
OPA-03 & AGTCAGCCAC & 10 & 10 & $10(1)$ & 10 & 10 \\
OPA-07 & GAAACGGGTG & 10 & 10 & 10 & 10 & 10 \\
OPA-09 & GGGTAACGCC & 08 & $08(1)$ & $08(1)$ & 08 & $08(1)$ \\
OPA-10 & GTGATCGCAG & 09 & 09 & 09 & 09 & 09 \\
OPA-18 & AGGTGACCGT & 13 & 13 & $13(1)$ & $13(1)$ & 13 \\
OPE-01 & CCCAAGGTCC & 07 & 07 & 07 & 07 & 07 \\
OPE-06 & CCCAAGGTCC & 10 & 10 & 10 & 10 & 10 \\
OPF-03 & CCTGATCACC & 09 & 09 & 09 & 09 & 09 \\
OPF-04 & GGTGATCAGG & 12 & 12 & 12 & 12 & 12 \\
\hline
\end{tabular}

* Entre parênteses está indicado o número de locos polimórficos 
A Tabela 10 é idêntica à Tabela 9 , porém se refere às plântulas derivadas de meristemas retirados da variedade RB83-5486. Em 98 locos, 12 mostraram-se polimórficos $(12,24 \%)$. As taxas de polimorfismo para os diferentes meristemas foram: 3,06\% $\left(\mathrm{Me}_{2}\right), 2,04 \%\left(\mathrm{Me}_{4}\right), 4,08 \%\left(\mathrm{Me}_{6}\right), 3,06 \%$ $\left(\mathrm{Me}_{8}\right)$ e 4,08\% (Meg). A taxa média de polimorfismo foi de 3,27\%, com desvio padrão de 0,85 (Figura 9).

Tabela 10. Polimorfismo molecular em plântulas cultivadas in vitro. Foram avaliadas 30 plântulas oriundas de cinco meristemas retirados da variedade RB83-5486.

\begin{tabular}{ccccccc}
\hline Primers & $\begin{array}{c}\text { Sequência de } \\
\text { bases }\end{array}$ & \multicolumn{5}{c}{ Número de locos * } \\
\hline & & $M_{2}$ & $M_{4}$ & $M_{6}$ & $M_{8}$ & $M_{9}$ \\
OPA-02 & TGCCGAGCTG & $10(2)$ & $10(1)$ & $10(3)$ & $10(3)$ & $10(2)$ \\
OPA-03 & AGTCAGCCAC & $11(1)$ & 11 & $11(1)$ & 11 & 11 \\
OPA-07 & GAAACGGGTG & 10 & 10 & 10 & 10 & 10 \\
OPA-09 & GGGTAACGCC & 08 & $08(1)$ & 08 & 08 & $08(1)$ \\
OPA-10 & GTGATCGCAG & 09 & 09 & 09 & 09 & 09 \\
OPA-18 & AGGTGACCGT & 11 & 11 & 11 & 11 & 11 \\
OPE-01 & CCCAAGGTCC & 12 & 12 & 12 & 12 & 12 \\
OPE-06 & CCCAAGGTCC & 10 & 10 & 10 & 10 & 10 \\
OPE-07 & AGATGCAGCC & 12 & 12 & 12 & 12 & 12 \\
OPF-03 & CCTGATCACC & 08 & 08 & $08(1)$ & 08 & $08(1)$ \\
\hline
\end{tabular}

* Entre parênteses está indicado o número de locos polimórficos 

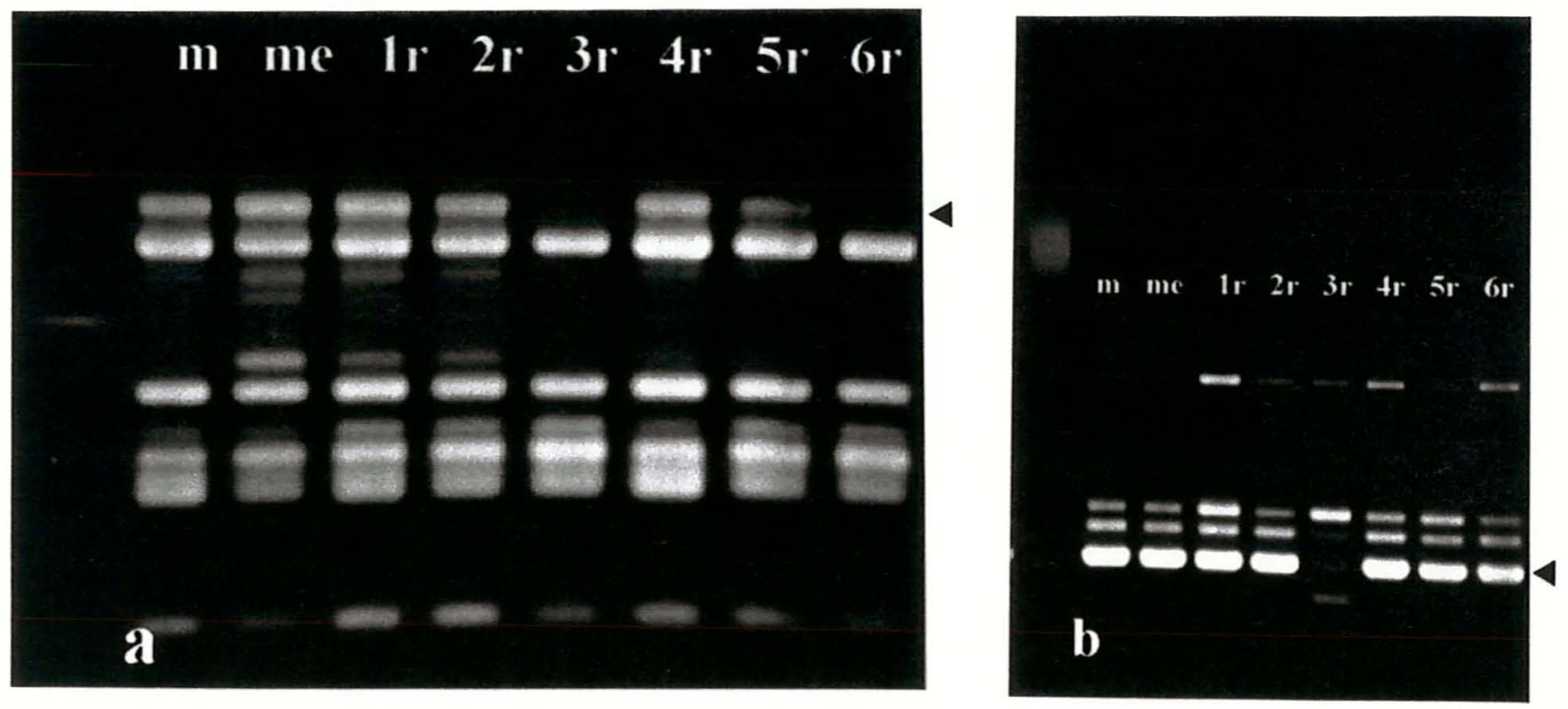

Figura 9. Perfil de RAPD de plantas de cana-de-açúcar da variedade RB835486, provenientes de um único meristema $(\mathrm{Me})$ nas seis fases de repicagens (1 a 6r); primer OPA-02 (a) e OPF-03 (b), ambos mostrando polimorfismo entre as repicagens. À esquerda está o marcador de peso molecular (Ladder $100 \mathrm{bp}$ ) e em seguida 0 perfil da planta mãe $(m)$, doadora do explante. 
A Figura 10 mostra que o número total de locos polimórficos na variedade RB83-5486 foi de 16 (16,3\%) enquanto que na SP80-185 foi de 6 $(6,12 \%)$. E que estes locos variam conforme a fase da cultura in vitro ( Figura 9).

Observou-se que o estresse in vitro ocorreu em todas as fases (repicagens) do processo de micropropagação da cana-de-açúcar para ambas variedades analisadas. Porém, constatou-se que a variedade RB83-5486 mostrou-se instável quando comparada à variedade SP80-185, do ponto de vista dos perfis de RAPD.

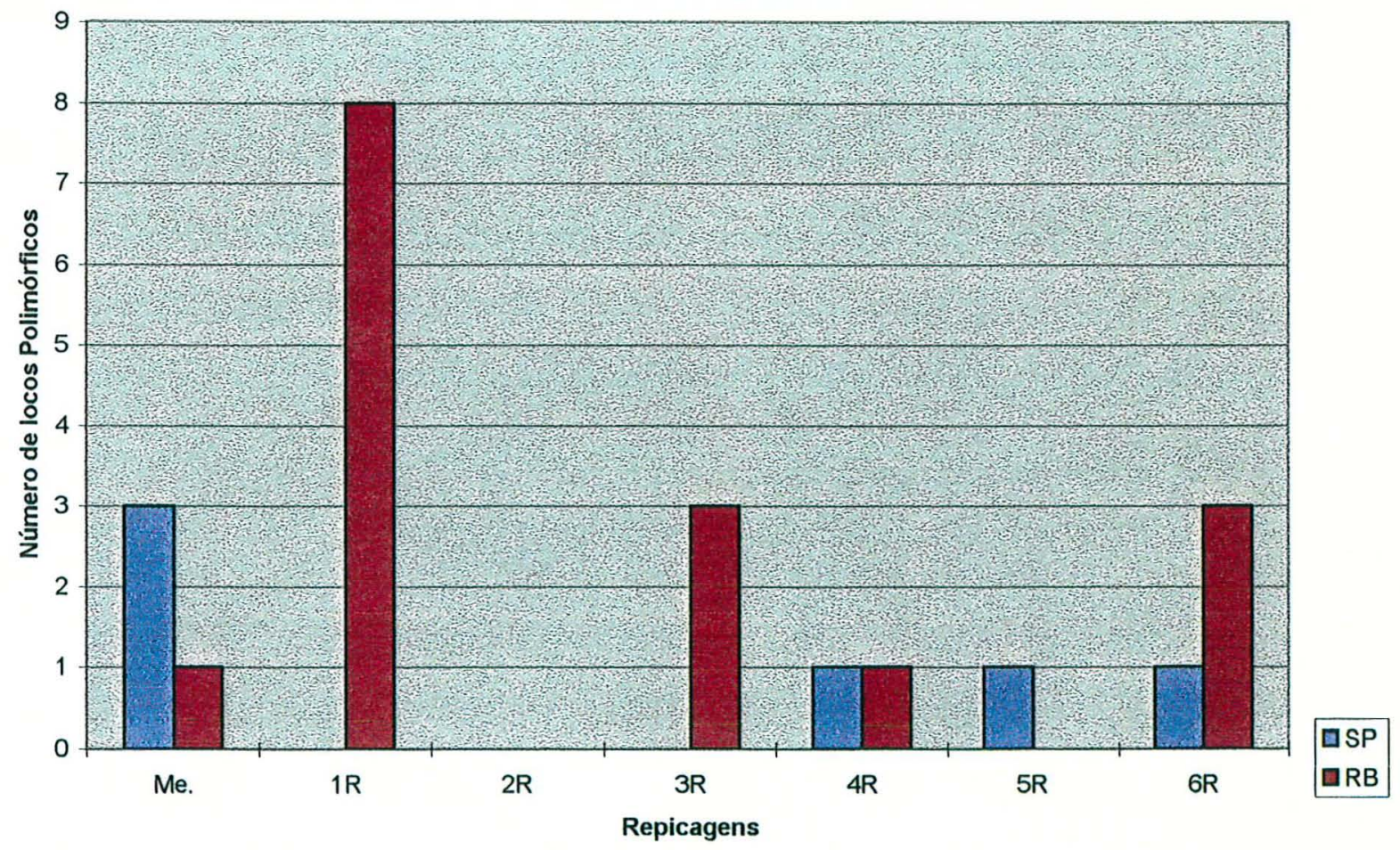

Figura 10. Número de locos polimórficos detectados em cada repicagem, considerando-se 30 plântulas da variedade RB83-5486 e 30 da variedade controle, SP80-185. 
Certos genótipos, como a variedade RB835486, talvez não se prestem para o cultivo in vitro da forma como é feito atualmente para os demais genótipos de cana-de-açúcar. Essa variedade é mais susceptível ao estresse, necessitando de protocolo mais adequado para o seu cultivo.

A cultura in vitro é considerada como um ambiente artificial e estressante, segundo Philips et al. (1990). Estes autores descrevem a cultura de tecidos como um procedimento altamente mutagênico. Atualmente, existem muitos relatos apontando os elementos transponíveis como sendo os causadores da variação somaclonal (Hirochika et al., 1996). Esta seria uma possivel explicação para o desaparecimento e reaparecimento de bandas de um loco de RAPD observados neste trabalho, particularmente durante as várias repicagens analisadas. 


\section{CONCLUSÕES}

Existe variabilidade molecular intrínseca aos clones de cana-de-açúcar e esta é da ordem de $1,02 \%$ de locos polimórficos, detectados pela técnica do RAPD.

A cultura de meristemas provoca incrementos de cerca de 7,0 vezes na taxa de polimorfismo molecular, detectado por RAPD, em cana-de-açúcar.

$O$ estresse in vitro ocorre em todas as fases (repicagens) do processo de micropropagação da cana-de-açúcar.

A variedade de cana-de-açúcar RB83-5486 tem um comportamento mais instável na cultura de tecidos, quando comparada à variedade SP80-185, do ponto de vista dos perfis de RAPD. Essa variedade é mais susceptivel ao estresse in vitro, necessitando de protocolo adequado para o seu cultivo. 


\section{REFERÊNCIAS BIBLIOGRÁFICAS}

BACCARIN, J. Agroindústria Sucroalcooleira .SP. Assembléia Legislativa, 1996, p.10

BAILEY, R. A.; BECHET, G. R. A comparison of seedcane derived from tissue culture with conventional seedcane. Proceeding of The South African Technologists' Association, n. 63, 125-129, 1989.

BERWALE, U. B.; WINDHOLM, J. M. Soybean: plant regeneration and somacional variation. In: BAJAJ, Y. P. (ed.): Biotechnology in agriculture and forestry 10: Legumes and oilssed crops I. London: Springer-Verlag, 1990, p. 114-133.

BINSFIELD P. C.; PETERS J. A.; AUGUSTIN, E. Isoenzymatic variation in potato somaclones (Solanum tuberosum). Brazilian Journal of Genetics, v.19, n.1, p.117-121, 1996.

BREARS, T.; CURTIS C. J.; LONSDALE, D. M. A especific rearrangement of mitocondrial DNA induceded by tissue culture. Theoretical and Applied Genetics, v.77, p.620-624, 1989. 
BREIMAN, A.; SHIMRON-ABARBANELL, D. Comprehensive molecular characterization of tissue-culture-derived Hordeum marinum plants. Theoretical and Applied Genetics, v. 83, p. 71-80, 1991.

BRETELL, R. I. S.; PALLOTTA, M.; GUSTAFSON, R.; APPELS, R. Variation at the NOR loci in Triticale derived from tissue culture. Theoretical and Applied Genetics, v. 71, p. 637-643, 1986.

BRETTELL, R. I. S.; DENNIS, E. S. Reactivation of a silent Ac following tissue culture and associated with heritable alterations in its methylation pattern. Molecular and General Genetics, v. 229, p. 365-372, 1991.

BROWN, P. T. H, DNA methylation in plants and its role in tissue culture. Genome, v. 31, p. 717-729, 1989.

BROWN, P. T. H.; MÜLLER, E.; SHIMAMOTO, K.; LÖRZ, H. Genetic variation in tissue culture-derived rice plants. In: RICE GENETICS II: PROCEEDING OF SECOND INTERNATIONAL RICE GENETICS SYMPOSIUM. p. 389400, Germany, 1991.

BURNER, D. M.; GRISHAM, M. P. Induction and stability of phenotypic variation in sugarcane as affected by propagation procedure. Crop Science, v. 35, p. 875-880, 1995.

BUTENKO, R. G.; SHEMINA, Z. B.; FROLOVA, L. V. Induced organogenesis and characteristics of plants produced in tobacco tissue culture. Genetika, v. 3, p. 29-39, 1967.

CHARLESWORTH, B.; SNIEGOWSKI, P.; STEPHAN, W. The evolucionary dynamics of repetitive DNA in eukaryotes. Nature, v. 371, p. 215-220, 1994. 
CHOMET, P. S.; WESSLER, S.; DELLAPORTA, L. S. Inativation of the maize transposable element Activator (Ac) is associated with DNA modification. EMBO Journal, v. 6, n. 2, p. 295-302, 1987.

CHOWDHURY, M. K. U.; VASIL, I. K. Molecular analysis of plant regenerated from embriogenic cultures of hybrid sugarcane cultivars (Saccharum spp.). Theoretical and Applied Genetics, v. 86, p. 181-188, 1993.

CHOWDHURY, M. K; SCHAEFFER. G. W.; SMITH., R. F. Molecular analysis of organelle DNA of different subspecies of rice and the genomic stability of mt DNA in tissue culture cells of rice. Theoretical and Applied Genetics, v. 76, p. $533-539,1988$.

CLOUTIER, S.; LANDRY, B.S. Molecular markers applied to plant tissue culture. In vitro Cellular and Developmental Biology, v. 30, p. 32-39, 1994.

CÔNSOLI, L. Análise genética e molecular da variação somaclonal em Stylosanthes guianensis (Leguminosae). Piracicaba, 1995. 108p. Tese (Mestrado) - Escola Superior de Agricultura "Luiz de Queiroz", Universidade de São Paulo.

D'AMATO, F. Nuclear change in cultured plant cells. Caryologia, v. 44, p. 217224, 1991.

DAHLEEN, L. S.; RIES, H.W.; STUTHMAN, D. D. Avenin banding pattern variation in tissue culture-derived oat lines. Crop Science, v. 31, p. 16631668, 1991. 
DAMASCO, O P.; GRAHAM, G.C.; HENRY, R. J.; ADKINS, S. W.; SMITH, M. K.; GODWIN, I. D. Random amplified polymorphic DNA (RAPD) detection of dwarf off-types in micropropagated Cavendish (Musa spp. AAA) bananas. Plant Cell Reports, v. 16, p. 118-123, 1996.

DANIELS, J.;ROACH, B. T. Taxonomy and evolution. In: HEINZ, D. J. (Ed.): Sugarcane improvement through breeding. New York: Elsevier, 1987. p. 7-84.

EVANS, D. A. Somaclonal variation - genetic basis and breeding applications Trends in Genetics, v. 5, p. 46-50, 1989.

FALCO, M. C. Transformação de cana-de-áçucar para a resistência ao herbicida glufosinato de amônio, via biolística. Piracicaba, 1998. 129p. Tese (Doutorado) - Escola Superior de Agricultura "Luiz de Queiroz", Universidade de São Paulo.

FEDOROFF, N. V. Maize transposable elements. In: BERG, D. E.; HOWE, M. M. Mobile DNA. Washington: American Society for Microbiology, 1989. p.375-407.

FEDOROFF, N. V.; CHANDLER, V. Inativation of maize transposable elements, In: PASZKOWSKI, J. (Ed.) Homologous recombination and gene silencing in plants, Dordrecht: Kluwer, 1994. p. 349-385.

FEDOROFF, N. V.; SHLÄPPI, M.; RAINA, R. Epigenetic regulation of the maize Spm transposon. BioEssays, v. 17, p. 291-297, 1995. 
FERNANDES, A. C. Produção e produtividade de cana-de-açúcar no Brasil. In: CONGRESSO NACIONAL DA SOCIEDADE DE TÉCNICOS AÇÚCAREIROS E ALCOOLEIROS DO BRASIL, Maceió, 1996. Anais. Macéio: STAB, 1996, p. 602-612.

FISH, N.; KARP, A. Improvement in regeneration from protoplasts of potato and studies on chromosome stability 1 . The effect of initial culture media. Theoretical and Applied Genetics, v. 72, p. 405-412, 1986.

FLUMINHAN, A.; AGUIAR-PERECIN, M. L. R.; SANTOS, J.A. Evidence for heterochromatin involvement in chromosome breakage in maize callus culture. Annals of Botany, v. 78, p. 73-81, 1996.

FORD-LLOYD, B. V.; NEWBURY, H, J.; MUNTHALI, M. The detection of somaclonal variants of beet using RAPD. Plant Cell Reports, v. 15, p. 474$478,1996$.

FORD-LLOYD, B. V.; SABIR, A.; NEWBURY, H, J.; TODD, C.; CATTY, J. Determination of genetic stability using isozymes ands RFLPs in beet plants regenerated in vitro. Theoretical and Applied Genetics, v. 84, p. 113-117, 1992.

HARDING, K.; BENSON, E. E.; ROUBELAKIS-ANGELAKIS, K. A. Methylated DNA changes associated with the initiation and maintenance of Vitis vinifera in vitro shoot and callus cultures: A possible mechanism for age-related changes. Vitis, v. 35, n. 2, p. 79-85, 1996.

HASHIMI, G.; HUETTEL, R.; MEYER, R.; KRUSBERG, L.; HAMMERSCHLAG, F. RAPD analysis of somaclonal variants derived from embryo callus culture of peach. Plant Cell Reports, v. 16, n. 9, p. 624-627, 1997. 
HEINZ, D. J.; MEE, W. P. Morphologic, cytogenetic, and enzymatic variation in Saccharum species hybrid clones derived from callus tissue. American Journal of Botany, v. 58, n. 3, p. 257-262, 1971.

HEINZE, B.; SCHMIDT J. Monitoring genetic fidelity vs somacional variation in Norways spruce (Picea abies) somatic embriogenis by RAPD analysis. Euphytica, v. 85, p. 341-345, 1995.

HESLOP-HARRISON, J. S.; BRANDES, A.; TAKETA, S.; SCHIMIDT, T. et al. The cromossomal distribuition of Ty1/copia group retrotransposable elements in higher plants and their implications for genome evolution. Genetica, v. 100, p. 197-204, 1997.

HIROCHIKA, $\mathrm{H}$. Activation of tabacco retrotransposon during tissue culture. EMBO Journal, v. 12, n. 6, p. 2521-2528, 1993.

HIROCHIKA, H. Regulation of plant retrotransposons and their use for genome analysis. Gamma Field Symposia, n. 34,1995.

HIROCHIKA, H.; SUGIMOTO, K; OTSUKI, Y.; TSUGAWA, H.; KANDA, M. Retrotransposon of rice involved im mutations induced by tissue culture. Proceedings of the National Academy Science of the United States of America, v. 97, p. 7783-7788, 1996.

HOLLIDAY, R. The inheritance of epigenetic defects. Science, v. 238, p. 163$169,1987$.

IRVINE, J. E.; BENDA, G.T.A.; LEGENDRE, B. L.; MACHADO JUNIOR, G. R. The frequency of marker changes in sugarcane plants regenerated from callus culture. Plant Cell, Tissue and Organ Culture, v. 3, p. 201-209, 1984. 
IRVINE, J. E. The frequency of marker changes in sugarcane plants regenerated from callus culture, II. Evidence for vegetative and genetic transmission, epigenetic effects and chimeral disruption. Plant Cell Tissue and Organ Culture, v. 26, p. 115-125, 1991.

JOACHIMIAK, A.; PRZYWARA, L.; ILNICKI, T.; KOWALSKA, A. Megachromosomes in tissue culture of Allium. Genetica, v. 90, p. 35-40, 1993.

KOVARIK, A.; KOUKALOVÁ, B.; BEZDÉK, M.; OPATRNÝ, Z. Hypermethylation of tabacco heterochromatic loci in response to osmotic stress. Theoretical and Applied Genetics, v. 95, p.301-306, 1997.

KUNITAKE, H.; NAKASHIMA, T.; MORI, K. TANAKA, M. Somaclonal and chromosomal effects of genotype, ploidy and culture duration in Asparagus officinalis L. Euphytica, v. 102, p. 309-316, 1998.

KUNZE, R; SAEDLER, H.; LÖNNING, W. E. Plant transposable elements. Classic Papers Advances in Botanical Research, v. 27, p. 332-436, 1997.

LARKIN, P.; SCOWCROFT, W. R. Somaclonal variation - A novel source of variability from cell cultures for plant improvement. Theoretical and Applied Genetics, v. 60, p. 197-214, 1981.

LARKIN, P.; SCOWCROFT, W. R. Somaclonal variation and eyespot toxin tolerance in sugarcane. Plant Cell, Tissue and Organ Cultures, v. 2, p. $11-121,1983$.

LEE, M.; PHILLIPS, R. L. Genomic rearrangements in maize induced by tissue culture. Genome, v. 29, n.1, p. 122-128, 1987. 
LEE, T. S. G. Micropropagation of sugarcane (Saccharum spp.) Plant Cell, Tissue and Organ Culture, v. 10, p. 47-55, 1987.

LEWIN, B. Genes V Oxford: University Press, 1994. cap. 28, p. 797-844: Chromosomes consist of nucleosomes.

LIU, M. C. Surgarcane. In: SHARP, W. R.; EVANS, D. A.; AMMIRATO, P. V.; YAMADA, Y. (Ed.): Handbook of plant cell culture. New York: Macmillan, 1984. v.2, 572-602.

LOSCHIAVO, F.; PITTO, L.; GIULIANO, G.; TORTI, G.; NUTI-RONCHI, V.; MARAZZITI, D.; VERGARA, R.; ORSELLI, S.; TERZI, M. DNA methylation of embryogenic carrot cell cutures and its variations as caused by mutation, differentiation, hormones and hypomethylating drugs. Theoretical and Applied Genetics, v. 77, p. 325-331, 1989.

MANTELL, S. H.; MATTHEWS, J. A.; MCKEE, R. A. Princípios de biotecnologia em plantas. Ribeirão Preto: Sociedade Brasileira de Genética, 1994. Cap. 5, p. 101-148: Técnicas de cultura de tecidos.

MATZKE, M. A.; MATZKE, A. J. M. Differential inactivation and methylation of a transgene in plants by two suppressor loci containing homologous sequences. Plant Molecular Biology, v.16, p. 821-830, 1991.

MCCLINTOCK, B. The significance of responses of the genome challenge. Science, v. 226, p. 792-801, 1984.

MEINS JUNIOR, F. Heritable variation in plant cell culture. Annual Review Plant Physiology, v. 34, p. 327-347, 1983. 
MEYER, P.; LINN, F.; HEIDMANN, I.; MEYER, H., NIEDENHOF, I.; SAEDLER, $\mathrm{H}$. Endogenous and environmental factors influence $35 \mathrm{~S}$ promoter methylation of maize A1 gene construct in transgenic petunia and its colour phenotype. Molecular and General Genetics, v. 231, p. 345-352, 1992.

MITSUI. Japan Sugar, Starch and Ethanol Yearbook. Mitsui \& Co. Ltd. 1995 $65 p$.

MURASHIGE, T.; SKOOG, F. A revised medium for rapid growth and biossay. with tabacco tissue culture. Plant Phisiology, v. 15, p. 473-497, 1962.

MURRAY, M. G.; THOMPSON, W.F. Rapid isolation of high molecular weight plant DNA. Nucleic Acids Reserch, v. 8, p. 1134-1137, 1980.

NELKE, M.; NOWAK, J.; WRIGHT, J.M., MCLEAN, N. L. DNA fingerprinting of red clover (Trifolium pratense L.) with Jeffrey's probes: detection of somaclonal variation and other applications. Plant Cell Reports, v. 13, p. 72-78, 1993.

OROPEZA, M.; GUEVARA, P.; GARCÍA, E.; RAMÍREZ, J. L. Identification of somaclonal variants of sugarcane (Saccharum spp.) resistant to sugarcane mosaic virus via RAPD markers. Plant Molecular Biology Reporter, v. 13, n. 2, p. 182-191, 1995.

PALMER, J. D.; SHIELDS, C. R. Tripartire structure of the Brassica campestris mitocondrial genome. Nature, v. 307, p. 437-440, 1984.

PESCHKE, V. M.; PHILLIPS, R, L. Genetic implications of somaclonal variation in plants. Advances in Genetics, v. 30, p. 41-75, 1992. 
PESCHKE, V. M.; PHILLIPS, R. L.; GENGENBACH, B. G. Discovery of transposable element activity among progeny of tissue culture-derived maize plants. Science, v. 238, p. 804-807, 1987.

PESCHKE, V. M.; PHILLIPS, R. L.; GENGENBACH. B. G. Genetic and molecular analysis of tissue-culture-derived Ac elements. Theoretical and Applied Genetics, v. 82, p. 121-129, 1991.

PHILLIPS, R.L., KAEPPLER, S.M.; PESCHKE V.M. Do we understand somaclonal variation? Progress in Plant Cellular and Molecular Biology. In: INTERNATIONAL CONGRESS ON PLANT TISSUE AND CELL CULTURE, Amsterdam, 1990.

RANI, V.; PARIDA, A.; RAINA, S.N. Random amplified polymorphic DNA (RAPD) markers for genetic analysis in micropropagated plants of Populus deltoides Marsh. Plant Cell Reports, v. 14, p. 459-462, 1995.

RODE, A.; HARTMANN, C.; HENRY, Y.; DE BUYSER, J.; AUBRY, C.; AUBRY, C. Identification of new mitocondrial genome organizations in wheat plants regenerated from somatic tissue cultures. Theoretical and Applied Genetics, v. 77, p. 169-175, 1989.

ROGERS, S.O.; BENDICH, A.J. Extraction of DNA from milligram amounts of fresh, herbarium and mummified plants tissues. Plant Molecular Biology, v. 5, p. $69-76,1985$.

RONEMUS, M. J.; GALBIATI M.; TICKNOR C.; CHEN, J.; DELLAPORTA, S.L. Demethylation-induced developmental pleitropy in Arabidopsis. Science, $v$. 273, p. 654-657, 1996. 
SALEH, N. M.; GUPTA, H. S.; FINCH, R. P. Stability of mitocondrial DNA in tissue-cultured cell rice. Theoretical and Applied Genetics, v. 79, p. 342$346,1990$.

SANO, H.; KAMADA, I.; YOUSSEFIAN, S.; KATSSUMI, M.; WABIKO, H. A single treatment of rice seedlings with 5-azacytidine induces heritable dwarfism and undermethylation of genome DNA. Molecular and General Genetics, v. 220 , p. $441-447,1990$.

SANTOS, J. A. Estudo da instabilidade cromossômica em cultura de longa duração de calos de milho. Piracicaba, 1995. 172p. Tese (Mestrado) Escola Superior de Agricultura "Luiz de Queiroz", Universidade de São Paulo.

SCHNEIDER, S.; ZYPRIAN, E. Detection of somaclonal variation in grapevine regenerants from protoplasts by RAPD-PCR. Vitis, v. 35 , n. 2. p. 99-100, 1996.

SCORTECCI, K. C.; DESSAUX, Y.; PETIT, A.; VAN SLUYS, M-A. Somatic excison of the Ac transposable element in transgenic Arabidops thaliana after 5-azacytidine treatment. Plant Cell Physiology, v. 38, n.3, p. 336$343,1997$.

SCOWCROFT, W. R.; DAVIS, P.; RYAN, S. A.; BRETTELL, R. I .S.; PALLOTTA, M. A.; LARKIN, P .J. The analysis of somaclonal mutants. In: FREELING, M.; ALAN, R. (Ed.) Plant genetics, New York, 1985. p.799815.

SILVAROLLA, M. B. Plant genomic alterations due to tissue culture. Journal of the Brazilian Association for the Advancement of Science, v. 44, n. 5, p. 329-335, 1992. 
SMULDERS, M .J .M.; RUS-KORTEKASS, W.; VOSMAN, B. Tissue cultureinduced DNA methylation polymorphisms in repetitive DNA of tomato calli and regenerated plants. Theoretical and Applied Genetics, v. 91, p. 1257-1264, 1995.

SREENIVASAN, T.V.; AHLOOWALIA, B.S.; HEINZ, D.J. Citogenetics. In: HEINZ, D. J. (Ed.) Sugarcane improvement through breeding. Amsterdam: Elsevier, 1987, cap. 5, p. 211-253.

TAYLOR, P. W. J.; GEIJSKES, J. R.; KO, H-L.; FRASER, T. A.; HENRY, R. J.; BIRCH, R. G. Sensitivity of random amplified polymorfic DNA analysis to detect genetic change in sugarcane during tissue culture. Theoretical and Applied Genetics, v. 90, p. 1169-1173, 1995.

TODOROVISKA, E.; TRIFONOVA, A.; PETROVA, M.; VITONOVA Z., MARINOVA. E., et al., Agronomic performance and molecular assessement of tissue culture derived barley lines. Plant Breeding, 1977, v.166, n.6, p.511-517.

VALLÉS, M. P.; WANG, Z. Y.; MONTAVON, P.; POTRYKUS, I.; SPANGENBERG, G. Analysis of genetic stability of plant regenerated from suspension cultures and protoplasts of meadow fescue (Festuca pratensis Huds.). Plant Cell Reports, v. 12, p. 101-106, 1993.

VIEIRA, M. L. C.; FUNGARO, M. H. P.; JUBIER, M-F.; LEJEUNE, B. Determination of taxonomic relationships among Braziliam taxa of Stylosanthes Sw., Leguminosae, using RAPD markers. Pesquisa Agropecuária Brasileira, v. 32, p. 305-310, 1997. 
WALLNER, E.; WEISING, K.; ROMPF, R.; KAHL, G.; KOPP, B. Oligonucleotide fingerprinting and RAPD analysis of Achillea species: Characterization and long-term monitoring of micropropagated clones. Plant Cell Reports, v. 15, p. $647-652,1996$. 